\title{
GERHARD LOHFINK - ŻYCIE, TWÓRCZOŚĆ I RECEPCJA W POLSCE
}

W 2006 r. staraniem wydawnictwa „W drodze” ukazały się na rynku polskim trzy dzieła Gerharda Lohfinka, znanego niemieckiego egzegety Nowego Testamentu. Liczący się na polu współczesnej teologii autor stał się tym samym bardziej dostępny szerszemu gronu czytelników w Polsce. Poczytność jego książek, tłumaczenia na wiele języków, przywoływanie jego opracowań w źródłach wielu dzieł teologów i biblistów, zarówno w Polsce ${ }^{1}$, jak i za granicą ${ }^{2}$, wreszcie

* Michał Rychert, absolwent Akademii Teologii Katolickiej w Warszawie. Ukończył studia specjalistyczne z teologii fundamentalnej. Doktoryzował się na Wydziale Teologicznym UMK w Toruniu na podstawie pracy poświęconej teologii królestwa Bożego G. Lohfinka.

${ }^{1}$ Zob. przypis 96.

${ }^{2}$ Niektóre przykłady obecności G. Lohfinka w zagranicznej literaturze teologicznej, biblijnej i teologiczno-fundamentalnej: A. Dańczak, La questione dello stato intermedio nella teologia cattolica negli anni 1962-1999, Romae 2002, s. 15-25; S. Dianich, Ecclesiologia, Cinisello Balsamo 1993; M. Dumais, Il discorso della montagna, Torino 1999; W. Egger, Handlungsorientierte Auslegung der Antithesen Mt 5,21-48, w: (red.) K. Kertelge, Ethik im Neuen Testament, Freiburg im Breisgau 1984 s. 119-144; H. Fries, Teologia Fondamentale, Brescia 1987; M. Kehl, la Chiesa, Cinisello Balsamo 1995; tenże, La Chiesa come instituzione, CThF, s. 200-225; K. Kertlage, La realtà della Chiesa nel Nuovo Testamento, CThF, s. 108-135; K. Lehman, Gemeinde, w: (red. K. Kertelge) F. Böcke, Christlicher Glaube in moderner Gesellschaft, Freiburg im Breisgau 1988, s. 5-65;. H. Merklein, La signora di Dio nell'annuncio di Gesù, Brescia 1994; A. Nitrola, Trattato di escatologia, Cinisello Balsamo 2001; R. Penna, Paolo di Tarso, Cinisello Balsamo 1992; S. Pič-Ninot, Gesù e la Chiesa, w: Dizionario di Teologia Fondamentale, (red.) R. Latourelle, R. Fisichella, Assisi 1990, s. 151-162; tenże, Wprowadzenie do eklezjologii, Kraków 
wrażliwość na współczesne problemy Kościoła, a przede wszystkim udział w wielu ważnych dla współczesnej teologii dyskusjach sprawiają, że twórczość teologiczna i egzegetyczna G. Lohfinka jest niezwykle aktualna, godna odnotowania i szerszego omówienia.

Celem niniejszego artykułu, uwzględniając ograniczone ramy prezentacji, jest zasygnalizowanie najważniejszych dzieł i obszarów tematycznych myśli teologicznej G. Lohfinka. Jako że teologia tybińskiego egzegety splata się w sposób niezmiernie istotny $\mathrm{z}$ elementami biografii, stąd wskazane $\mathrm{w}$ tytule dwa elementy: życie i twórczość nie są i nie mogą być zaprezentowane w separacji, ale łączą się tam, gdzie jego teologia łączy się z egzystencjalnymi decyzjami. Chcemy również zwrócić szczególną uwagę na aktualność myśli niemieckiego egzegety na polskim obszarze teologicznym, a stąd wynika trzeci punkt - recepcja w Polsce. Opracowanie zamyka bibliografia dzieł Lohfinka, która jest nie tylko podsumowaniem jego dotychczasowego dorobku, ale ponadto wyraża intencję, aby niniejsze opracowanie mogło stać się narzędziem pracy dla tych wszystkich, którzy zechcieliby bliżej zapoznać się z twórczością tybińczyka.

\section{1. ŻYCIE}

Gerhard Lohfink przychodzi na świat 29 sierpnia 1934 r. we Frankfurcie nad Menem. Tam w 1954 r. w gimnazjum klasycznym im. Heinricha von Gagen zdaje maturę. Studia rozpoczyna od germanistyki i łaciny na Uniwersytecie Goethego. Począwszy od 1955 r. podejmuje studia filozoficzne i teologiczne na Uniwersytecie S. Georgen we Frankfurcie nad Menem. W latach 1957-1958 równolegle studiuje na Fakultecie Teologii Katolickiej Uniwersytetu w Monachium. W 1960 r. składa egzamin końcowy z teologii. Również w tym samym roku przyjmuje święcenia w diecezji Limburg. Po studiach przez trzy lata (1961-1963) pracuje w duszpasterstwie jako kapelan w parafii św. Urszuli w Oberursel koło Frankfurtu. Od 1964 r. kontynuuje studia teologiczne na uniwersytecie w Würzburgu pod kierunkiem Rudolfa Schnackenburga.

2002; R. Pesch, Voraussetzungen und Anfünge der urchristlichen Mission, w: (red.) K. Kertelge, Mission im Neuen Testament, Freiburg im Breisgau 1982, s. 11-70; H. J. Pottmeyer, La questione della vera Chiesa, CThF, s. 243-278; G. Sauter, L'origine della Chiesa dalla parola e dello spirito di Dio, CThF, s. 226-242; K. H. Schelkle, Izraele nel Nuovo Testamento, Brescia 1991; R. Schnackenburg, Ist der Gedanke des Sühnetodes Jesus der einzige Zugang zum Verständnis unserer Erlösung durch Jesus Christus?, w: (red.) K. Kertelge, Der Tod Jesu, Freiburg im Breisgau 1976, s. 205-230; H. Schürmann, Regno di Dio e destino di Gesù, Milano 1986; G. Segalla, Teologia biblica del Nuovo Testamento, Torino 2006; J.-M. Tillanrd, Chiesa di Chiese, L'ecclesiologia di comunione, Brescia 1989. W. Trilling, L'annuncio di Gesù, Brescia 1986; H. Waldenfels, O Bogu, Jezusie Chrystusie i Kościele - dzisiaj, Katowice 1993. 
W 1965 r. publikuje swoje pierwsze dzieło Paulus vor Damaskus (Pawet pod Damaszkiem), a następnie Die Bibel: Gotteswort in Menschenwort (Biblia: stowo Boga w stowach ludzkich). Zainteresowanie postacią i teologią św. Pawła będzie wyznaczało jeden z wielu, choć nie najważniejszy, kierunek zainteresowań towarzyszący Lohfinkowi w późniejszej pracy twórczej.

W 1971 r. na uniwersytecie w Würzburgu broni pracę doktorską zatytułowaną: Die Himmelfahrt Jesu. Untersuchungen zu den Himmelfahrts und Erhöhungstexten des Lukas (Wniebowstapienie Jezusa. Studium nad zagadnieniem wniebowstapienia $i$ zmartwychwstania $u$ św. Łukasza) $)^{3}$. W pracy tej przedstawił pogląd dotyczący historycznego pojmowania wniebowstąpienia. Uznał w niej za niewłaściwe pytanie o historyczność wniebowstąpienia Jezusa. Zarówno zmartwychwstanie, jak i wniebowstąpienie nie należą do sfery porządku ziemskiego ${ }^{4}$. Problem, jak słusznie zauważa W. Kasper, leży w relacji języka mitologicznego do historii ${ }^{5}$. Praca ta opublikowana w tym samym roku zajęła ważne miejsce w dyskusji teologicznej nad rozumieniem historycznego i teologicznego znaczenia zmartwychwstania i wniebowstąpienia. Mieliśmy tego przykład również na terenie polskim, ponieważ w kolekcji "Communio" pod wspólnym tytułem „Wniebowstąpienie Chrystusa” ukazało się kilka artykułów, w których autorzy odwołują się do tez Lohfinka6.

Nicią przewodnią teologii tybińczyka stanie się refleksja nad podwójnym dziełem św. Łukasza. Punktem wyjścia była rozprawa habilitacyjna pt.: Die Sammlung Israels. Eine Untersuchung zur lukanischen Ekklesiologie (Zgromadzenie Izraela. Studium nad eklezjologia św. Łukasza) opublikowana w 1975 r. ${ }^{7}$ Praca ta szybko została zauważona również poza granicami Niemiec i otrzymała bardzo dobre recenzje jako prawdziwy wzór poszukiwań biblijnych, prezentujący świeże i kompetentne spojrzenie na polu teologii Nowego Testamentu ${ }^{8}$. W tym samym roku ukazuje się dzieło, którego Gerhard Lohfink

${ }^{3}$ G. Lohfink, Die Himmelfahrt Jesu. Untersuchungen zu den Himmelfahrts und Erhöhungstexten des Lukas, München 1971.

${ }^{4}$ Tamże, s. 276. Zob. tenże, Der historische Ansatz der Himmelfahrt Christi, s. 73, Catholica 17 (1963), s. 44-84.

${ }^{5}$ W. Kasper, Wniebowstapienie Chrystusa - historia i teologiczne znaczenie, s. 49, Communio 6 (1986) 1, s. 48-57.

${ }^{6}$ M. Gesteira, Wniebowstapienie a Eucharystia, Communio 6 (1986) 1, s. 94-109 (cyt. s. 96-97); M. Giutton, Teologia czterdziestu dni, tamże, s. 35-47 (cyt. s. 37, 38); W. Kasper, Wniebowstapienie Chrystusa - historia i teologiczne znaczenie, tamże, s. $48-57$ (cyt. s. $48,49,51,53$ ); J. Łach, Wstapit na niebiosa, tamże, s. 11-19 (cyt. s. 17, 18); A. M. Sicari, Konieczność wniebowstapienia, tamże, s. 3-10 (cyt. s. 3, 4).

${ }^{7}$ G. Lohfink, Die Sammlung Israels. Eine Untersuchung zur lukanischen Ekklesiologie, München 1975. Prezentacja pracy habilitacyjnej dokonała się w 1973 r.

${ }^{8}$ Por. M. Làconi, [Rec.] G. Lohfink, La raccolta di Israele. Una ricerca sell'ecclesiologia lucana, Marietti, Casale Monferrato 1983, ss. 137, s. 337 i 339, RiBl, 35 (1987) 1, s. 337-339. 
jest współautorem wraz z Gisbertem Greshake, znanym niemieckim teologiem, poświęcone zagadnieniom eschatologii chrześcijańskiej pt. Naherwartung - Auferstehung - Unsterblichkeit: Untersuchungen zur christlichen Eschatologie ${ }^{9}$. Nowatorska jak na ówczesne czasy teza o „zmartwychwstaniu w śmierci” czy też teza, że „każdy człowiek żyje w czasie ostatecznym” wywołały zaciętą polemikę, którą podjął przede wszystkim J. Ratzinger ${ }^{10}$. Stanowiła ona podstawę do dalszej dyskusji, do której włączyli się m.in. K. Rahner, U. H. von Balthasar, czy wreszcie W. Kasper ${ }^{11}$. Książka ta spotkała się z dużym zainteresowaniem również pośród szerszego grona czytelników. Pod wpływem powtarzających się próśb o przygotowanie dzieła bardziej przystępnego dla szerszej rzeszy odbiorców w 1976 r. Lohfink publikuje niewielką książeczkę poświęconą właśnie zagadnieniom eschatologii pt.: Der Tod ist nicht das letzte Wort (Śmierć nie jest ostatnim słowem $)^{12}$. Refleksja nad eschatologią wywarła szczególny wpływ na decyzje życiowe Lohfinka, stąd stanowi niezwykle ważny element biografii, była poddawana modyfikacjom, a tym samym świadczy o ciągłym dojrzewaniu otwartości intelektualnej i duchowej.

W swojej pierwszej refleksji eschatologicznej wychodzi od ogólnej obserwacji:

Kto czyta Ewangelie synoptyczne obiektywnie i bez założeń wstępnych nie może pominąć następującego faktu: Jezus przepowiadał bezpośrednią bliskość czasową panowania Bożego, w tym znaczeniu, że panowanie to objawi się już teraz i rozpocznie się definitywnie jeszcze w obecności współczesnego Mu pokolenia. Innymi słowy: Jezus oczekiwał przyjścia Boga, sądu i końca świata jeszcze w czasie swoich słuchaczy ${ }^{13}$.

Jak zrozumieć zawartą w orędziu Jezusa „bezpośrednią bliskość” czasową panowania Bożego? Pytanie to stanowi główną oś, wokół której niemiecki egzegeta kształtuje swój model eschatologiczny, a którego głównym zamierzeniem jest przełożenie „bliskiego oczekiwania” na współczesny język i wyobrażenia ${ }^{14}$.

${ }^{9}$ G. Lohfink, Zur Möglichkeit christlicher Naherwartung, s. 38-81, w: tenże, G. Greshake, Naherwartung - Auferstehung - Unsterblichkeit: Untersuchungen zur christlichen Eschatologie, Freiburg im Breisgau 1975.

${ }^{10}$ J. Ratzinger, Śmierć i życie wieczne, Warszawa 1986, s. 128-129.

${ }^{11}$ Zob. W. Kasper, Nadzieja na ostateczne przyjście w chwale Jezusa Chrystusa, Com 7 (1987) 2, s. 32-46.

${ }^{12}$ Der Tod ist nicht das letzte Wort, Freiburg im Breisgau, 1976. (tłum. włoskie) La morte non è l'ultima parola, Bari 1993.

${ }^{13}$ G. Lohfink, Zur Möglichkeit christlicher Naherwartung, s. 38. Od strony teologii dogmatycznej ten model eschatologiczny został omówiony w pracy: A. Dańczak, La questione dello stato intermedio nella teologia cattolica negli anni 1962-1999, Romae 2002, s. 15-25.

${ }^{14}$ Por. G. Lohfink, Zur Möglichkeit christlicher Naherwartung, s. 78. 
Uznaje za absurdalny pogląd, że "Jezus miał na względzie pewien rodzaj 'bezczasowej' bliskości panowania Boga"15. Dochodzi więc do wniosku, że wydarzeniem, przez które przychodzi królestwo Boże, które jest jednocześnie bliskie i nieznane (co do daty swego przyjścia), jest śmierć. Jest to wydarzenie, które wskazuje na inny ważny aspekt eschatologii, a mianowicie uniwersalny i ostateczny charakter działania Bożego. Model ten nie był ostatnim słowem Tybinczyka. Pytanie o bezpośrednią bliskość czasową panowania Bożego stanie się ostatecznie osnową głównego nurtu jego teologii. Model „bliskiego oczekiwania" w śmierci, ostatecznie stał się tylko prototypem dojrzalszej formy myślenia o eschatologii, która zostanie wyartykułowana na zakończenie kariery uniwersyteckiej.

W 1973 r. Lohfink otrzymuje nominację Konsylium Naukowego na stanowisko profesora Nowego Testamentu na Fakultecie Teologii Katolickiej Uniwersytetu w Tybindze. Jako wieloletni wykładowca egzegezy Nowego Testamentu jest członkiem zespołu redakcyjnego kwartalnika teologicznego "Theologische Quartalschrift", autorem licznych publikacji, artykułów, recenzji i książek oraz współautorem wielu dzieł. Większość artykułów i recenzji publikuje we wspomnianym "Theologische Quartalschrift” - periodyku Uniwersytetu w Tybindze oraz "Biblische Zeitschrift” - kwartalniku Wydziału Teologicznego Uniwersytetu w Würzburgu.

Gerhard Lohfink bierze udział w wielu sympozjach naukowych, między innymi $w$ kongresie teologicznym $w$ Trier (19-23.09.1983 r.) odbywającym się pod hasłem: „Radykalizm i kompromis w etyce chrześcijańskiej” i wygłasza referat pt.: Zur Radikalität des Ethischen im Matthäusevangelium ${ }^{16}$. W tym samym roku uczestniczy również $\mathrm{w}$ sympozjum biblijnym w Lucernie (22.03.1983) poświęconym etyce Nowego Testamentu ${ }^{17}$, na którym przedstawia zagadnienie adresatów Kazania na Górze w referacie zatytułowanym: Wem gilt die Bergpredigt? Eine redaktionskritische Untersuchung von Mt 4,23-5,2 und 7,28f (Kogo dotyczy Kazanie na Górze? Krytyczne badanie Mt 4, 23-5, 2. 7, 28). W 1984 r. na sympozjum zorganizowanym przez Akademię diecezji Rottenburg i Stuttgard w Hohenheim zatytułowanym: Kirchenträume - Kirche als Kontrastgesellschaft? (Sen o Kościele - Kościót jako społeczność alternatywna?), podczas którego referuje temat: Powotanie Kościoła, aby być społecznościq alternatywnq ${ }^{18}$. Natomiast w Roku Jubileuszowym uczestniczy $\mathrm{w}$ sympozjum zorganizowanym $\mathrm{w}$ Watykanie na

${ }^{15}$ Tamże, s. 50.

${ }^{16}$ Por. G. Lohfink, Per chi vale il discorso della montagna? Contributi per un'etica cristiana, Brescia 1990, s. 63.

${ }^{17}$ Por. J. Chmiel, Etyka w Nowym Testamencie, Sympozjum Biblijne w Lucernie 1983, RBL 6 (1983), s. 552-553.

${ }^{18}$ Por. G. Lohfink, Per chi vale il discorso della montagna? Contributi per un'etica cristiana, Brescia 1990, s. 99. 
temat źródeł antysemityzmu: „Radici dell'antigiudaismo in ambiente cristiano" (Źródła antysemityzmu w środowisku chrześcijańskim), w czasie którego, wygłasza referat pt.: Antijudaismus bei Paulus?: die Kirche und Israel in 1 Thess 2,14-16 und Röm 9-11 (Antyjudaizm u Pawta? Kościót i Izrael w 1 Tes 2, 14-16 i Rz 9-11) ${ }^{19}$, którym potwierdza raz jeszcze swoją kompetencję w zakresie teologii św. Pawła ${ }^{20}$.

W życiu i twórczości teologicznej G. Lohfinka można dostrzec jak nieustannie konfrontował on swoje doświadczenie Kościoła z Pismem Św. Postawy i przemyślenia wynikające $z$ tej konfrontacji niejednokrotnie ulegały zmianom. Był teologiem poszukującym. Nie zawsze należał do umysłów pokornych. Przeżył również czas buntu, gdy po opublikowaniu Humanae vitae Pawła VI, jeździł z kazaniami i wystosował "gniewny list” do kardynała Döpfnera z Monachium jako wyraz swojego sprzeciwu ${ }^{21}$. W latach 60. należał do wielkiej rzeszy tych postępowych teologów, którzy chcieli wszystko zmienić „od Watykanu po najmniejszą parafię". W tej reformatorskiej euforii wydawało się, że zmiana struktur, odrzucenie „kościelnej pompy”, języka, liturgii, stroju, celibatu, wprowadzenie kapłaństwa kobiet, demokratycznych wyborów biskupa, rozwodów kościelnych, samo przez się, dokona prawdziwej odnowy Kościoła. Jak wyznaje, z biegiem lat uświadamiał sobie ,jak wątpliwa była lista zmian proponowanych wówczas przez niektórych liderów”, do których on sam z entuzjazmem się odnosił. Z perspektywy lat odpowiadając na niemal retorycznie już brzmiące pytanie: czy rzeczywiście doszłoby do odnowy Kościoła, gdyby do tego wszystkiego dopuszczono? - wyznaje, że dla odnowy Kościoła potrzeba czegoś więcej - nawrócenia ${ }^{22}$. Dzisiaj widzi w tym wewnętrznym niepokoju ślad tęsknoty za Kościołem, w którym można by w sposób konkretny doświadczyć wspólnoty wiary. Wraz ze wzrostem tej świadomości Lohfink coraz bardziej odwraca się od modnych i atrakcyjnie brzmiących tematów swoich wykładów i kazań ku eklezjologii i to nie tylko w sposób czysto teoretyczny. Był to zarazem zwrot ku najważniejszemu nurtowi jego egzegetycznych poszukiwań, ku teologii królestwa Bożego, który posiadał również swój wymiar egzystencjalny.

${ }^{19}$ G. Lohfink, Antijudaismus bei Paulus?: die Kirche und Israel in 1 Thess 2,14-16 und Röm 9-11, w: Radici dell'antigiudaismo in ambiente cristiano, Vaticano 2000, s. 163-196.

${ }^{20}$ Wykaz innych książek i artykułów z zakresu teologii św. Pawła: Paulus vor Damaskus, Stuttgart 1965; Die Normativität der Amtsvorstellungen in den Pastoralbriefen, TQ 157 (1977) 2, s. 93-106; Die Vermittlung des Paulinismus zu den Pastoralbriefen, BZ 32 (1988) 2, s. 169-188; Paulinische Theologie in der Rezeption der Pastoralbriefe, w: (red.) K. Kertelge, Paulus in den neutestamentlichen Spätschriften. Zur Paulusrezeption im Neuen Testament, Freiburg im Breisgau 1981, s. 70-121.

${ }^{21}$ G. Lohfink, Moje doświadczenie Kościoła, s. 471, w: Czy Bóg potrzebuje Kościoła?, s. $463-479$.

${ }^{22}$ Tamże, s. 472. 
W 1986 r. ${ }^{23}$ Lohfink rezygnuje z kariery uniwersyteckiej. Na spotkaniu pożegnalnym wygłasza pożegnalny referat, opublikowany później w „Theologische Quartalschrift"24, który stanowi zarazem manifest nowego modelu eschatologicznego, a jednocześnie usprawiedliwienie dla podjętej decyzji, by swoje życie i posługę kapłańską związać ze wspólnotą Katholische Integrierte Gemeinde (Katolicka Gmina Zintegrowana) działającą od lat w Monachium² ${ }^{25}$ Tak pisze o swojej decyzji:

Ja sam, gdy przed 14 laty w Tybindze zacząłem wykłady, przyjąłem sobie tę koncepcję i często ją wygłaszałem. Wierzyłem wtedy, że w ten sposób można rozwiązać problem bliskiego oczekiwania. A mianowicie, że paruzja Chrystusa i postać końcowa basilei znajdują początek w śmierci człowieka w miejscu, gdzie w obleczonym blaskiem przemienionym czasie cała historia ulegnie transcendencji i zostanie objęta. Ponieważ śmierć każdemu człowiekowi jest bliska, to również przez śmierć bliska staje się paruzja Chrystusa i ostateczne przyjście królestwa ${ }^{26}$.

Tym samym po 14 latach od pierwszej szeroko dyskutowanej publikacji poświęconej zagadnieniom eschatologii Lohfink znacznie modyfikuje swoje stanowisko. Przyznaje, że nie mógłby więcej formułować tezy, że końcowa postać basylei znajduje początek w śmierci człowieka, nie dlatego, że ten model jest całkowicie błędny, ale dlatego, że podkreślanie bliskości królestwa w śmierci było naznaczone jednostronnością i właśnie z powodu tej jednostronności model ten nie jest zgodny z biblijną wizją eschatologii ${ }^{27}$. Tym samym w znacznym stopniu modyfikuje swoje stanowisko zawarte we wspomnianym „Zur Möglichkeit christlicher Naherwartung", aby bliskość królestwa Bożego opisać w trzech wymiarach: czasu, postaci społecznej i sprawcy królestwa Bożego 28 .

Zwrot eschatologiczny, jaki dokonuje się w świadomości i życiu Lohfinka, zawiera również odpowiedź na pytanie o nowość i oryginalność Nowego względem Starego Testamentu. Niemiecki egzegeta stwierdza, że oryginalność Nowego Testamentu nie wyraża się ani w przykazaniu miłości, ani zwrotem ku wnętrzu człowieka, ani personalizmem i odkryciem jednostki jako podmiotu.

${ }^{23}$ W biogramach redakcyjnych książek Lohfinka, wydanych w Polsce jako datę zakończenia pracy na uniwersytecie podawany jest zwykle rok 1987, jednakże sam Lohfink podaje rok 1986, por. G. Lohfink, Czy Bóg potrzebuje Kościoła?, s. 463.

${ }^{24}$ G. Lohfink, Die Not der Exegese mit der Reich-Gottes-Verkündigung Jesu, TQ 168 (1988) 1, s. 1-15.

${ }^{25}$ Więcej na temat Katholische Integrierte Gemeinde wspólnoty zob. www.kig-online.de.

${ }^{26}$ G. Lohfink, Die Not der Exegese mit der Reich-Gottes-Verkündigung Jesu, s. 14.

${ }^{27}$ Por. G. Lohfink, Die Not der Exegese mit der Reich-Gottes-Verkündigung Jesu, TQ 168 (1988) 1, s. 1-15.

${ }^{28}$ Te trzy elementy wyznaczają strukturę artykułu. Por. tamże. 
Błędną ścieżką jest szukanie nowości Jezusa na drodze przeciwstawiania Starego Nowemu Testamentowi ${ }^{29}$. Co zatem stanowi o nowości i oryginalności Nowego Testamentu? Tybinczyk odpowiada, że o ile decydującą właściwością Starego Testamentu jest jego otwarcie się na przyszłośćc ${ }^{30}$ i koncentracja na obietnicy, to decydującą właściwością Nowego Testamentu jest spełnienie. „To, że królestwo Boże ujawnia się teraz w historii jako zwycięskie, stanowi właśnie ową radosną nowinę" . Lohfink określa swój model eschatologiczny jako eschatologię "teraźniejszą" ${ }^{2}$. Zagadnienie ostatecznego czasu przyjścia królestwa Bożego sprowadza do stwierdzenia, według którego, jeżeli królestwo Boże ,jeszcze nie” jest w pełni obecne, to jest to wyłącznie skutek odrzucenia ze strony człowieka. Ze strony Boga można mówić tylko o ,już” zrealizowanym królestwie ${ }^{33}$. Wszelkie próby transcendowania królestwa Bożego w eschatologiczną przyszłość lub indywidualizowania panowania Bożego określa jako formy porzucenia eschatologii Nowego Testamentu. Królestwo Boże, aby w ogóle mogło być królestwem, musi posiadać swój wymiar społeczny. Bóg, aby przeprowadzić swój plan zbawienia, potrzebuje ludu, który przyjmie Jego panowanie. Stąd wypływa społeczna postać królestwa Bożego. Lud Boży nie jest jednak tylko biernym elementem panowania Bożego. Jest powołany, aby w wierze współdziałać z Bogiem w przemianie świata. Tak można najkrócej streścić główne tezy przełomowego w życiu Lohfinka wystąpienia $^{34}$. Zwrot ku społecznemu pojmowaniu królestwa Bożego i „eschatologii teraźniejszej" jest momentem kluczowym dla zrozumienia dalszej twórczości teologicznej Lohfinka. Wszystkie późniejsze dzieła pisane są już w nurcie tego nowego spojrzenia na eschatologię i eklezjologię.

Lohfink, rozstając się z uczelnią, nie zaprzestaje pracy naukowej. Nadal tworzy oraz wygłasza wykłady na zaproszenia różnych środowisk. W ramach

${ }^{29}$ Por. G. Lohfink, Czy Bóg potrzebuje Kościoła?, s. 192. Zasada jedności obu Testamentów jest zasadą niezwykle ważną w egzegezie, którą uprawia Lohfink. Dla niego nie jest to zasada czysto teoretyczna, ale jest stałą praktyką uwidaczniającą się w każdej kwesti. Sposób uprawiana egzegezy przez Lohfinka jest wzorcowym przykładem realizacji zasady, że Stary Testament znajduje swoje wyjaśnienie w Nowym, a Nowy kryje się w Starym.

${ }^{30}$ Por. tamże, s. 193.

${ }^{31}$ Tamże, s. 200.

32 Por. G. Lohfink, Czy Bóg potrzebuje Kościoła?, s. 214; Gesù e la Chiesa, s. 78, CThFt 3, Brescia 1990. G. Lohfink inspiracji do posłużenia się takim określeniem dla swojego modelu eschatologicznego zaczerpnął z J. Becker, Das Heil Gottes. Heils-und Sündenbegriffe in den Qumrantexten und im Neuen Testament, Göttingen 1964, s. 199-203; H. Merklein, Die Gottesherrschaft als Handlungsprinzip. Untersuchung zur Ethik Jesu, Würzburg 1984, s. 158-165. Także H. Schürmann mówi o eschatologii teraźniejszej, tenże, Regno di Dio e destino di Gesù, s. 62.

${ }^{33}$ Por. G. Lohfink, Czy Bóg potrzebuje Kościoła?, s. 216.

${ }^{34}$ Por. tenże, Die Not der Exegese mit der Reich-Gottes-Verkündigung Jesu, s. $1-15$. 
kursów teologicznych organizowanych każdego roku przez Accademia per la Teologia del Popolo di Dio/Akademie für die Theologie des Volkes Gottes z siedzibą w Villa Cavalletti pod Rzymem prowadzi wykłady dla różnych grup słuchaczy wraz z innymi znanymi profesorami, jak Rudolfem Peschem, Georgiem Braulikiem, czy też swoim bratem Norbertem Lohfinkiem ${ }^{35}$.

Przynależność do Katholische Integrierte Gemeinde stała się dla tybińczyka spełnieniem tęsknoty, spoczynkiem po długiej drodze, doświadczeniem wiary, z którego całymi garściami czerpie, dzieląc się namysłem nad wiarą z czytelnikami swoich dzieł. Doświadczenie gminy sprawia, że Kościół stał się dla niego nie tylko wyzwaniem intelektualnym, ale przede wszystkim powołaniem, środowiskiem życia, w którym można konkretnie doświadczyć wspólnoty wiary ${ }^{36}$. Tym, co potrzebuje współczesna egzegeza, jak twierdzi Lohfink, nie jest ani nową metodą, ani też bogatszą wiedzą szczegółową, jest nim przede wszystkim właściwe miejsce interpretacji. Tym miejscem winien być Kościół, którego doświadczenia byłyby zgodne z tymi doświadczeniami, które miał Kościół nowotestamentalny ${ }^{37}$. „W takim Kościele zrozumienie Jezusowego orędzia o królestwie Bożym nie stanowiłoby więcej problemu. W takim Kościele nawet wiecznie sceptyczni teolodzy mogliby powiedzieć: 'tak królestwo Boże naprawdę do nas przyszło'"'38. Wyjątkowość Lohfinka nie polega na samej tylko afirmacji powyższego stwierdzenia, ale przede wszystkim na dążeniu do ukazania społecznego i etycznego kształtu panowania Bożego.

Odnowa eschatologiczna przełomu XIX i XX w. zaowocowała wielością ujęć dotyczących czasu przyjścia panowania Bożego. W tym sensie stanowisko Lohfinka byłoby tylko kolejną próbą odpowiedzi na to wciąż na nowo podejmowane pytanie. Szczególna wartość Lohfinka polega z jednej strony na oderwaniu się od niekończących się pytań o to, co ,już", a co ",jeszcze nie", a z drugiej, co jest zasadniczym jego wkładem na „zobrazowaniu” teologii królestwa Bożego.

Nie da się zrozumieć G. Lohfinka, jego wyborów życiowych i teologii, a zwłaszcza eklezjologii bez tego rozdziału jego życia, który będąc wciąż otwarty, być może zaskoczy nas nowymi przemyśleniami i dziełami, które wzbogacą już i tak obfitą twórczość. Dla Lohfinka eklezjologia jest nie tylko wyzwaniem

${ }^{35} \mathrm{Na}$ temat programu i tematyki kursów zob. www.akademie-cavalletti.de.

${ }^{36}$ Por. G. Lohfink, Czy Bóg potrzebuje Kościoła?, s. 475.

${ }^{37}$ Por. Die Not der Exegese mit der Reich-Gottes-Verkündigung Jesu, s. 15.

${ }^{38}$ Tamże, s. 15. Lohfink wskazuje na żywą wspólnotę wiary - Kościól, jako na środowisko, w którym urzeczywistnia się orędzie o królestwie Bożym, i w którym „zrozumienie Jezusowego przepowiadania nie powinno stanowić więcej problemu". Stwierdzenie to jest tym samym uzasadnieniem, dla decyzji o porzuceniu pracy uniwersyteckiej i związaniu się z Katolicką Gminą Zintegrowaną. Miejscem uprawiania teologii nie jest abstrakcyjnie pojęty Kościół, ale ten doświadczany na co dzień we wspólnocie wiary i życia. 
o charakterze intelektualnym, jest przede wszystkim wyborem egzystencjalnym, o którym nie można tylko mówić lub pisać, „trzeba wyruszyć w drogę"39, trzeba tę rzeczywistość współtworzyć w otwarciu na żywe słowo Boga.

\section{TWÓRCZOŚĆ}

Tybińczyk przez udział w międzynarodowych sympozjach teologicznych oraz publikację swoich dzieł poza granicami Niemiec szybko zyskał sławę na forum międzynarodowym. Szczególnym uznaniem cieszyły się jego cztery, tłumaczone na wiele języków dzieła, które zarazem stanowią cztery filary jego teologii.

Pierwszym z nich jest wspomniane Die Sammlung Israels. Eine Untersuchung zur lukanischen Ekklesiologie (Zgromadzenie Izraela. Studium nad eklezjologia św. Łukasza), w którym na podstawie podwójnego dzieła św. Łukasza poszukuje odpowiedzi na pytanie o cel i sens misji Jezusa: czy misją Jezusa było założenie Kościoła? W jaki sposób Łukasz w swoim dziele rozumie początek Kościoła? Celem misji Jezusa było zgromadzenie eschatologicznego Izraela. Opierając się na tej tezie, formułuje pogląd, że Jezus w czasie swojej historycznej misji nie zakłada Kościoła. Ten bowiem rodzi się ze zwołania Izraela i z eschatologicznego przepowiadania królestwa Bożego. Nie można zatem mówić o „założeniu” Kościoła ani wskazać, w klasycznym tego słowa znaczeniu, historycznego momentu jego fundacji. Kościół jest wynikiem dynamicznego procesu historio-zbawczego ${ }^{40}$, który obejmuje sobą całą historię zbawienia i którym kieruje Bóg. Momentem najbardziej eklezjotwórczym, zdaniem Lohfinka, jest Zesłanie Ducha Świętego ${ }^{41}$. Wydarzenie to otwiera bowiem ostatni decydujący etap zgromadzenia Izraela aż do oddzielenia się Kościoła od Judaizmu. Kościół w myśli Lohfinka otrzymuje wyraźnie dynamiczny i teocentryczny charakter.

Zagadnienie założenia Kościoła kontynuuje w kolejnych opracowaniach, z których na szczególną uwagę zasługuje artykuł Jesus und die Kirche ${ }^{42}$, w którym pytanie o genezę Kościoła rozciąga poza dzieła Łukasza na inne znaczące eklezjologicznie księgi Nowego Testamentu. Artykuł ten z punktu widzenia teologii fundamentalnej zasługuje na szczególną uwagę. Został on opublikowany w trzecim tomie Handbuch der Fundamentaltheologie (Podręcznik teologii fundamentalnej, t. 3 - Traktat o Kościele), a tym samym pozwolił wpisać się Lohfinkowi nie tylko

${ }^{39}$ G. Lohfink, Czy Bóg potrzebuje Kościoła?, s. 477.

${ }^{40} \mathrm{G}$. Lohfink, La raccolta d'Israele. Una ricerca sull'ecclesiologia lucana, Casale Monferrato 1983 , s. 36 .

${ }^{41}$ Tenże, La raccolta d'Israele. Una ricerca sull'ecclesiologia lucana, s. 118.

${ }^{42}$ Tenże, Hat Jesus eine Kirche gestiftet?, TQ 161 (1981) 2, s. 81-97. Zob. tenże, Jesus und die Kirche, w: red. W. Kern-Hermann, J. Pottmeyer, M. Seckler, Handbuch der Fundamentaltheologie 3. Traktat Kirche, Freiburg im Breisgau 1985-1998, s. 49-96. 
$\mathrm{w}$ jedną z ważniejszych publikacji teologiczno-fundamentalnych ostatnich lat, ale przede wszystkim $\mathrm{w}$ dyskusję nad problemem dyskutowanym $\mathrm{w}$ ramach jej przedmiotu, potwierdzając przydatność swoich poszukiwań $\mathrm{w}$ refleksji teologiczno-fundamentalnej.

Kolejną pracą G. Lohfinka, na którą należy zwrócić uwagę, jest książka zatytułowana Wie hat Jesus Gemeinde gewollt? Zur gesellschaftlichen Dimension des christlichen Glaubens ${ }^{43}$ (Jakiej gminy chciat Jezus? Społeczny wymiar wiary chrześcijańskiej). Dzieło to zostało docenione nie tylko wśród specjalistów, ale również przez szeroką rzeszę czytelników. Potwierdzeniem tego może być fakt, że w ciągu niespełna dziesięciu lat doczekało się w Niemczech sześciu wznowień. Lohfink szuka w nim odpowiedzi na dwa zasadnicze pytania: (1) jakiej wspólnoty chciał Jezus? (2) jak powinien wyglądać Kościół, aby odpowiadał zamysłowi Jezusa? Książka ta stanowi pewnego rodzaju kontynuację poprzedniego dzieła Die Sammlung Israels. Tezy w nim zawarte stanowią punkt wyjścia dalszych poszukiwań egzegetycznych. Cel, jaki postawił sobie autor, wyraził słowami: „celem [tej książki] było ukazanie z perspektywy Nowego Testamentu, że wiara nakierowana jest na społeczność (Gemeinschaft) i to taką społeczność, która ma wyraźne kontury odróżniające ją od reszty społeczeństwa ${ }^{44}$. Chodzi w niej o nakreślenie kształtu propozycji zbawczej dla zwołanego Izraela. Propozycja ta, zdaniem Lohfinka, wyraża się we wspólnocie ludu Bożego, kierującego się nowym eschatologicznym etosem królestwa Bożego. Takie wartości, jak bezwarunkowa miłość, sprawiedliwość społeczna, odrzucenie podziałów społecznych, rezygnacja z przemocy, nadają wspólnocie eklezjalnej kształt nowej rodziny i czynią z niej wspólnotę alternatywną wobec innych społeczności. Sam projekt ukazany jest $\mathrm{w}$ trzech odsłonach. Pierwsza dotyczy działalności i orędzia Jezusa. Druga skupia się na praktyce pierwotnej gminy chrześcijańskiej. Trzecia ukazuje kontynuację zbawczego projektu Jezusa w erze wczesnochrześcijańskiej. Centralną ideą tego dzieła jest Kościół widziany jako wspólnota - temat ten Lohfink rozwija w opozycji do indywidualizmu i konsumizmu religijnego, które to postawy mogą dziś słusznie uchodzić za synonimy współczesnego kryzysu w Kościele. Niewątpliwie praca ta jest nowym i odważnym spojrzeniem na Kościół, które przybiera formę pewnego projektu eklezjologicznego. Dzieło to zostało dostrzeżone i docenione również w Polsce, w obrębie teologii fundamentalnej i określone jako bardzo interesująca oferta dla współczesnej eklezjologii, zawierająca pewne novum w propozycji

${ }^{43}$ G. Lohfink, Wie hat Jesus Gemeinde gewollt? Zur gesellschaftlichen Dimension des christlichen Glaubens, Freiburg 1982. Dzieło to zostało przetłumaczone na kilka języków: (wyd. angielskie) Jesus and comunity: the social dimension of Christian faith, Philadelphia 1984; (wyd. francuskie) L'Eglise que voulait Jésus, Paris 1985; (wyd. hiszpańskie) La Iglesia que Jesùs quería: dimensión comunitaria de la fe cristiana, Desclée de Brouwer 1986; (wyd. włoskie) Gesù come voleva la sua comunita? La Chiesa quale dovrebbe essere, Cinisello Balsamo 1987.

${ }^{44}$ G. Lohfink, Czy Bóg potrzebuje Kościota?, s. 476. 
odpowiedzi na pytanie o kształt i istotę Kościoła ${ }^{45}$. Jako takie posiada również walor ekumeniczny ${ }^{46}$ i pastoralny dotyczący sposobu obecności oraz nowego sensu misyjności Kościoła w świecie współczesnym ${ }^{47}$. Streszcza się on w wizji Kościoła jako wspólnoty alternatywnej.

Nie wszyscy jednak uznali wymiar pastoralny za walor tego dzieła. Niektórzy krytycy odnotowują, że schemat eklezjologiczny zaprezentowany w tym dziele jest związany z sytuacją egzystencjalną i doświadczeniem wspólnoty zaczerpniętej z Katolickiej Gminy Zintegrowanej. Wpływ doświadczenia jest tak daleki, że wydaje się osłabiać ostrze egzegetyczne tekstu biblijnego, co wyrażałoby się w przesadnym dążeniu do wskazania w Nowym Testamencie, a zwłaszcza w opisie życia wspólnoty pierwotnego Kościoła, schematu życia właściwego dla Gminy z Monachium zamiast dla całego Kościoła ${ }^{48}$. Z całą pewnością poprawności naukowej nie sprzyjają emocje, a rezultat badań nie może wynikać z kryteriów pozamaterialnych, jednakże kryterium tym nie może być również Kościół empiryczny, a doświadczenia wiary nie można traktować jako emocjonalnego rozproszenia. Doświadczenie życia wspólnotowego niewątpliwie dało Lohfinkowi nowe światło w rozumieniu orędzia Jezusa, co z pewnością ubogaca jego przekaz i teologię, czyni je bardziej przystępnym i zrozumiałym dla szerokiego odbiorcy.

Kolejnym ważnym dziełem, które zrobiło międzynarodową karierę, jest Wem gilt die Bergpredigt? Beiträge zu einer christlichen Ethik (Kogo dotyczy Kazanie na Górze? Przyczynek do etyki chrześcijańskiej) ${ }^{49}$. Praca ta, poza jedną częścią, ukazała się wcześniej w postaci artykułów, które zostały przepracowane do potrzeb tej publikacji ${ }^{50}$. Jest to praca o spójnej logice, zawierająca jasno sprecyzowany

${ }^{45}$ Por. A. Nowicki, [Rec.] Gerhard Lohfink, L'Eglise que voulait Jésus. Les editions du Cerf, Paris 1985, ss. 196, Colloquium Salutis, 18-19, 1986-1987, s. 380.

${ }^{46}$ Por. C. Ghiedelli, Gerhard Lohfink, Gesù come voleva la sua comunitá? La ekklesia come dovrebbe essere, s. 719, RCIt, 10 (1987), s. 718-719.

${ }^{47}$ S. Cipriani, Gesù come voleva la sua comunitá? Riflessioni su un recente libro di Gerhard Lohfink, s. 452-453, Asprenas 34 (1987), s. 432-454.

${ }^{48}$ G. De Virgilio, La EKKAH IIA come "società alternativa". Ricenzione dell'opera di G. Lohfink, s. 472, Rivista Biblica 39 (1991) 4, s. 467-475.

${ }^{49}$ Wem gilt die Bergpredigt? Beiträge zu einer christlichen Ethik, Freiburg im Breisgau 1988; (wyd. hiszpańskie), El Sermón de la montańa żpara quién?, Barcelona 1989; (wyd. włoskie) Per chi vale il discorso della montagna? Contributi per un'etica cristiana, Brescia 1990.

${ }^{50} \mathrm{G}$. Lohfink, Wem gilt die Bergpredigt? Eine redaktionskritische Untersuchung von Mt 4,23-5,2 und 7,28f, TQ 163 (1983) 4, s. 264-284 (część pierwsza książki); Der ekklesiale Sitz im Leben der Aufforderung Jesu zum Gewaltverzicht (Mt 5,39b-42/Lk 6,29f), TQ 162 (1982) 3, s. 236-253 (część druga); Gezetzeserfüllung und Nachfolge. Zur Radikalität des Ethischen im Matthäusevangelium, w: red. H. Weber, Der ethische Kompromi $\beta$, Studien zur theologischen Ethik 12, Freiburg im Breisgau 1984, s. 15-58 (stanowi część trzecią); Schwerter zu Pflugscharen! Die Rezeption von Jes 2,1-5 par Mi 4,1-5 in der Alten Kirche und im Neuen Testament, TQ 166 (1986) 3, s. 184-209 (stanowi część piątą). 
projekt badawczy, przez który autor w sposób jasny i konsekwentny przeprowadza czytelnika. G. Lohfink wychodzi od obserwacji, że Kazanie na Górze zbyt często jest odczytywane i interpretowane w kluczu indywidualizmu lub uniwersalizmu etycznego, co wypacza jego główne przesłanie, a niejednokrotnie wręcz niweluje przez fakt, że jest rozumiane jako zbyt radykalne, a w konsekwencji niemożliwe do realizacji. Autor jest przekonany, że różnorodność stanowisk i interpretacji Kazania na Górze wynika przede wszystkim z braku precyzyjnej identyfikacji jego adresatów. Dlatego pierwszym zadaniem, jakie sobie stawia, jest określenie adresatów Magna Charta chrześcijaństwa. Stanowi to punkt wyjścia, aby zmierzyć się z zagadnieniem radykalizmu wymogów etycznych postawionych w Kazaniu przez Jezusa. Wykazuje, że adresatem Kazania na Górze nie jest ani wyizolowana jednostka, ani tym bardziej cała ludzkość. Właściwym adresatem jest lud Boży końca czasów.

Równie ważnym wątkiem jest problematyka możliwości wprowadzenia w czyn moralnych wskazań Kazania na Górze. Odpowiedź tkwi w środowisku i sposobie realizacji. Kluczem jest środowisko Kościoła i zachowanie integralności wymagań etycznych, w czym Lohfink upatruje ich radykalizmu. Tak więc w pojęciu "radykalizm” nie tyle kryje się surowość, kategoryczność, czy też bezwarunkowość wymagań, jak to widział Kant, ale ich łączność i niepodzielność, która daje gwarancję ich realizacji ${ }^{51}$. Przykładem może być wezwanie do wyzbycia się przemocy czy zakaz rozwodów, które są poddane szczegółowej analizie. Oba wymagania są niewątpliwie radykalne i jako takie dla pełnej realizacji wymagają nie tylko indywidualnej wiary, ale przede wszystkim oparcia w środowisku wiary - we wspólnocie. Już w poprzednim dziele Wie hat Jesus Gemeinde gewollt?, które zawierało wiele tez przywołanych w rozważaniach poświęconych adresatom Kazania na Górze, pojawiło się zagadnienie wyzbycia się przemocy jako wyróżnika nowej rodziny, którą powoływał Jezus. Temat ten znajduje rozwinięcie $w$ niniejszym dziele $\mathrm{i}$ jest niewątpliwie jedną z kwestii, która czyni dzieło ważnym i prowokującym ${ }^{52}$. Wnioski, do jakich dochodzi Lohfink, idą niejako w poprzek wykładni Katolickiej Nauki Społecznej dotyczącej uprawnionej obrony z użyciem siły militarnej. Lohfink tą tematyką zajmuje się już w latach 1981-1982 w ramach cyklu wykładów na Uniwersytecie w Tybindze zatytułowanych: Polityka na rzecz pokoju - obrona - rozbrojenie ${ }^{53}$. Pozostaje pytanie, czy zagadnienie to ewoluowało $\mathrm{w}$ teologii Lohfinka, czy też przyjęło

${ }^{51}$ G. Lohfink, Per chi vale il discorso della montagna?, s. 75.

${ }^{52}$ L. Cilia, G. Lohfink, Per chi vale il discorso della montagna? Contributi per un'etica cristiana, s. 63, Rivista Biblica 39 (1991) 1, s. 61-63, podobnie wypowiada się w swojej recenzji S. Cipriani. Zob. tenże, G. Lohfink, Per chi vale il discorso della montagna? Contributi per un'etica cristiana, s. 541, Asperenas 4 (1991), s. 540-542.

${ }^{53}$ G. Lohfink, Per chi vale il discorso della montagna? Contributi per un'etica cristiana, Brescia 1990, s. 39. 
od razu ostateczny kształt, taki, jaki widzimy w Wem gilt die Bergpredigt? Możemy z całą pewnością wskazać, że pogląd na temat uzasadnienia odrzucenia przemocy jako biblijnego wymogu etycznego dzieli ze swoim bratem Norbertem, który tą tematyką zajmował się na polu Starego Testamentu ${ }^{54}$. Geneza tej problematyki u Lohfinka pozwala stanowczo odrzucić tezę według, której doszedł on do przeświadczenia o możliwości realizacji wskazań Kazania na Górze, a w tym nakazu zaniechania odwetu dzięki przynależności do Gminy Zintegrowanej ${ }^{55}$. Należy raczej stwierdzić, że teza ta wyrasta z wieloletnich poszukiwań i badań, solidnej krytyki tekstu biblijnego oraz dyskusji teologicznych ze swoim bratem. Jej słabością, a może geniuszem, jest brak przełożenia na język realiów współczesnego świata, pozostawienie otwartej furtki na różnorodne odpowiedzi. Co do jednej kwestii Lohfink jest jednak pewny. Kościół powinien dążyć z całej mocy, aby na tle świata jawić się jako wspólnota wolna od wszelkich form przymusu, przemocy i dyskryminacji. Dzieło to zostało zauważone również w Polsce i wzbudziło pozytywne wrażenie ${ }^{56}$. Jest to zarazem jedno z najczęściej cytowanych dzieł Lohfinka w polskich opracowaniach teologicznych.

Wreszcie niezwykle ważnym dziełem jest Braucht Gott die Kirche? Zur Theologie des Volkes Gottes, które doczekało się również wydania polskiego: Czy Bóg potrzebuje Kościoła?, wcześniej zataczając szeroki krąg wśród odbiorców w różnych krajach ${ }^{57}$. Wydawca polski, wydawnictwo „W drodze”, tak zachęca do lektury tej książki:

Gerhard Lohfink w sposób fascynujący, z niezwykłą świeżością i przejrzystością opowiada dzieje zbawienia i odkrywa nieustannie obecną w tych dziejach tęsknotę Boga za nowym społeczeństwem Bożej sprawiedliwości,

${ }^{54}$ N. Lohfink, "Święta wojna" i „klątwa” w Biblii, Communio 53 (1989) 5, s. 10-19, zob. także Il Dio violento dell'Antico Testamento e la ricerca d'una societá non - violenta, Civiltà Cattolica 3211 (1984) II, s. 30-48; Il Dio della Bibbia e la violenza, Brescia 1985.

${ }^{55} \mathrm{~J}$. Łach, „Konstytucja” Królestwa Bożego (Mt 5-7; Łk 6,20-49), s. 88, w: Ksiądz Rektor Jan Each Kaptan i Biblista, (red.) R. Bartnicki, Warszawa 2004, s. 65-435. Ideę do swojej tezy o wyrzeczeniu się przemocy Lohfink zaczerpnął z prac R. Girarda, a zwłaszcza z tezy, według której społeczeństwa świeckie za pomocą przemocy i sankcji utrzymują porządek społeczny, natomiast królestwo Boże poprzez miłość ostatecznie eliminuje konieczność stosowania wszelkiej represji i przemocy w stosunkach międzyludzkich, Zob. tenże, Sacrum i przemoc, Poznań 1993, Koziot ofiarny, Łódź 1987.

${ }^{56}$ Tamże, s. 102.

${ }^{57}$ G. Lohfink, Braucht Gott die Kirche? Zur Theologie des Volkes Gottes, Freiburg im Breisgau 1998; (wyd. angielskie) Does God need the church?: toward a theology of the people of God, Collegeville 1999; (wyd. włoskie) Dio ha bisogno la Chiesa? Sulla teologia del popolo di Dio, Cinisello Balsamo 1999; (wyd. hiszpańskie) Necesita Dios la Iglesia?, San Pablo 2001; (wyd. polskie) Czy Bóg potrzebuje Kościoła? O teologii ludu Bożego, Poznań 2005. 
za Kościołem - za ludem, który przez wiarę i głoszenie radosnej nowiny pozwoli Bogu spełnić pierwotny zamysł: obdarowania człowieka szczęściem $\mathrm{i}$ autentycznego przemienienia świata $\mathrm{w}$ ziemię obiecaną.

Słowa te w sposób niezwykle celny i syntetyczny oddają główny zamysł książki. Jest to dzieło poniekąd wieńczące dotychczasowy rozwój myśli eklezjologicznej tybińczyka. Na tle dotychczasowej twórczości nie zaskakuje nowymi oryginalnymi tezami. Tym, co zasługuje na uwagę, jest skoncentrowanie historii zbawienia wokół idei królestwa Bożego. Na to pytanie „Czy Bóg potrzebuje Kościoła?" G. Lohfink odpowiada, przeprowadzając czytelnika przez cztery części zamknięte refleksją na temat osobistego doświadczenia Kościoła. W pierwszym rozdziale zostaje ukazana dynamika historii zbawienia, która jest również historią wolności człowieka. Bóg potrzebuje Kościoła, o ile historia zbawienia ma dotyczyć wolnych osób. Bóg tylko przez ludzi i ich wolność i w takiej mierze, w jakiej dadzą się pociągnąć pięknem sprawy Bożej może realizować historię $z_{\text {zbawienia }}^{58}$. Bóg potrzebuje Kościoła ponieważ realizuje swój plan zbawczy odwołując się do wolności człowieka. Projektem Boga jest nowa społeczność, lud Boży, Kościół, który poprzez poddanie się Jego panowaniu może zrealizować swoją misję - przynieść światu zbawienie. Z perspektywy Boga można mówić wyłącznie o wypełnieniu obietnicy. Ze strony Boga wszystko zostało już dane ${ }^{59}$. Poprzez to stwierdzenie Lohfink precyzuje swoje stanowisko na tle różnych modeli eschatologicznych, jakie wyłoniły się po odnowie eschatologicznej przełomu wieków i określa je jako eschatologię „teraźniejszą”. Odrzuca tym samym stanowiska skrajne eschatologii konsekwentnej i zrealizowanej, sytuując się pośród egzegetów napięcia, czyniąc z wolności człowieka klucz hermeneutyczny jej zrozumienia ${ }^{60}$.

Wspomniano już o walorze ekumenicznym dzieł Lohfinka. W tym miejscu wymaga on bliższego omówienia. Zagadnienia ekumenizmu Lohfink łączy z tematem wiarygodności Kościoła w świecie współczesnym. Jak stwierdza, Kościół potrzebuje jedności, a największą raną Kościoła jest jej utrata ${ }^{61}$. Kościół potrzebuje również pojednania ze swoją historią, a więc również z ludem Izraela $^{62}$. Nie mniejszą raną jest bowiem również oderwanie się od synagogi, a co gorsza - zwrócenie się przeciwko niej. Jest to zdecydowanie szersze pojmowanie jedności i ekumenizmu niż to, do którego przywykliśmy.

${ }^{58}$ Por. G. Lohfink, Czy Bóg potrzebuje Kościoła?, s. 82.

${ }^{59}$ Por. tamże, s. 216.

${ }^{60}$ Por. M. Rychert, Spoteczno-historyczny wymiar królestwa Bożego w teologii Gerharda Lohfinka, Seminare, 24 (2007), s. 177-190.

${ }^{61}$ Por. G. Lohfink, Czy Bóg potrzebuje Kościoła?, s. 434.

${ }^{62}$ Por. tamże, s. 431. 
Gerhard Lohfink jawi się jako teolog dialogu, który w retrospektywnym spojrzeniu próbuje na nowo określić miejsce i rolę Kościoła w świecie współczesnym. Jest bacznym obserwatorem życia Kościoła. Krytycznie ocenia zmiany religijności europejskiej dokonujące się pod wpływem idei postmodernistycznych. Jego eklezjologia jest wołaniem o Kościół bardziej zintegrowany, wspólnotowy, czytelny, a jednocześnie bardziej radykalny i misyjny. Teologia Lohfinka, dzięki jego osobistemu związaniu się ze wspólnotą Katholische Integrierte Gemeinde, nie jest refleksją abstrakcyjną, czysto akademicką, uprawianą zza biurka, ale pomimo zawiłości egzegetycznych jest refleksją, która porusza i prowokuje. Jest to teologia ze wszech miar biblijna, która wyrasta z doświadczenia wiary i poszukuje treści w historii zbawienia zapisanej na kartach Pisma Świętego. Prezentuje styl myślenia wolny od neofickiej zapalczywości czy ekskluzywizmu. Kunszt egzegetyczny uwidacznia się na każdej stronie jego dzieł. Styl pisarski jest wolny od wyniosłości, a rygoryzm egzegetyczno-naukowy łączy się z prostym, przystępnym językiem, który zdradza pewne zamierzenie pastoralne. Głównym przesłaniem dzieł Lohfinka jest to, aby królestwo Boże ukazać jako porywającą rzeczywistość, projekt życia, drogę zbawienia, a nie jako skomplikowany problem teologiczny. Idea królestwa Bożego pozwala mu nie tylko wyrazić centralne przesłanie Jezusa, wyakcentować istotę eklezjologii biblijnej, ale przede wszystkim wskazać na jedność wewnętrzną Nowego Testamentu.

Królestwo Boże jako osnowa myśli teologicznej jest dla Lohfinka nie tylko teoretycznym zagadnieniem egzegetycznym, ale również „problemem” praktycznym. To połączenie teologii królestwa Bożego i wiary pozwala mu na formułowanie odważnych tez teologicznych, ale również na krytyczne spojrzenie na kondycję Kościoła. Lohfink nie należy do krytyków malkontentów, jego wizja historii zbawienia pozwala na tworzenie wizji Kościoła pełnej nadziei. W swoich dziełach nie tyle koncentruje się na demaskowaniu słabości i grzechów Kościoła, co raczej na tworzeniu pozytywnego programu dla wspólnoty wiary pod panowaniem Boga.

Gerhard Lohfink należy do teologów o bardzo jasnych i sprecyzowanych poglądach. Takie zagadnienia, jak: odrzucenie przemocy, wspólnota (gemeinde - gmina), Kościół jako społeczność alternatywna, kwestia założenia Kościoła, możliwość stosowania etyki Nowego Testamentu, teologia królestwa Bożego, stanowią najbardziej wymowne i rozpoznawalne motywy jego twórczości. Jest człowiekiem rozmiłowanym w Biblii, księga ta jest pasją jego życia oraz inspiracją naukową i pastoralną. W czasie lektury jego dzieł narzuca się spostrzeżenie, że księgę tę chciałby wszystkim przybliżyć i uczynić dla każdego czytelnika jasną i zrozumiałą ${ }^{63}$. Zadnie to realizuje poprzez wskazanie, że Biblia mimo całej

${ }^{63}$ Por. S. Grzybek, [Rec.] Gerhard Lohfink, Rozumieć Biblię, Warszawa 1987, ttum. polskie B. Widta, ss. 142 , s. 543 , RBL 6 (1987), s. 542-544. 
swej wewnętrznej różnorodności, jednoczy się wokół idei panowania Bożego. W swoich badaniach egzegetycznych stosuje metodę historyczno-krytyczną z zachowaniem reguły jedności Biblii ${ }^{64}$. Pozwala mu to pokazać wydarzenia biblijne w kontekście historii zbawienia z zachowaniem rygorów obiektywności naukowej.

Bóg Lohfinka nie jest Bogiem zamkniętym w kartach Biblii. Jest Panem całej historii, którego dzieła wciąż się dokonują ${ }^{65}$, i którego działanie doświadcza w swojej wspólnocie, który wreszcie pozwala z taką odwagą wskazywać na aktualność i możliwość realizacji orędzia Jezusa. Jest to Bóg żywy, wciąż przemawiający, który przeprowadza z udziałem naszej wolności swój plan zbawienia.

\section{RECEPCJA TWÓRCZOŚCl LOHFINKA W POLSCE}

Ostatnie publikacje dzieł Lohfinka bynajmniej nie były pierwszym znakiem jego obecności w Polsce. Już w 1987 r. pojawia się jego wczesne dzieło zatytułowane: Rozumieć Biblię. Wprowadzenie do krytyki form literackich ${ }^{66}$. Dzieło to, ze względu na duże walory dydaktyczne, zostało przyjęte ciepło i z wielkim uznaniem jako godne polecenia szerokiej rzeszy czytelników ${ }^{67}$. Autor, kierując się wskazaniami encykliki Divino Afflante Spiritu i konstytucją soborową Dei Verbum, bierze pod uwagę formę tworzywa narracyjnego. Respektując wielość form występujących w Piśmie Świętym, nakierowuje myśl na główną zasadę, jaką należy zachować przy lekturze Biblii, a mianowicie na zachowanie reguły jedności Biblii ${ }^{68}$. Dzieło to znalazło również oddźwięk w innych krajach, w których cieszyło się nie mniejszym powodzeniem. Po długiej przerwie, dopiero w 2006 r. polskiemu czytelnikowi zostały udostępnione kolejne dzieła:

${ }^{64}$ G. Lohfink zwraca uwagę i przestrzega przed deprecjonowaniem Starego Testamentu. Wspólnie ze swoim bratem Norbertem podziela spostrzeżenie, że w praktyce homiletycznej mamy wciąż do czynienia z praktycznym marcjonizmem przejawiającym się poprzez przeciwstawianie Starego Nowemu Testamentowi zob. Pieśń chwaty. Chrześcijanin a Stary Testament, Warszawa 1982.

${ }^{65}$ Taki jest również tytuł jednej z książek wydanych przez G. Lohfinka, Gottes Taten gehen weiter, Freiburg im Breisgau 1985.

${ }^{66}$ Tytuł oryginału: Jetzt verstehe ich die Bibel. Ein Sachbuch zur Formkritik, Stuttgart, 1973. (Wyd. polskie) Wydawnictwo PAX, Warszawa 1987. (Wyd. hiszpańskie) Ahora entiendo la Biblia: crítica de las formas, Madrid 1977. (Wyd. włoskie) Ora capisco la Bibbia. Studio sulle forme letterarie della Bobbia, Bologna 1981.

${ }^{67}$ Por. E. Strycharz, [Rec.] Gerhard Lohfink, Rozumieć Biblię. Wprowadzenie do krytyki form literackich, PAX Warszawa 1987, ss. 138, Katecheta 3 (1988) 185, s. 139-140. S. Grzybek, [Rec.] Gerhard Lohfink, Rozumieć Biblię, Warszawa 1987, ttum. polskie B. Widta, ss. 142, RBL 6 (1987), s. 542-544.

${ }^{68}$ Por. G. Lohfink, Rozumieć Biblię. Wprowadzenie do krytyki form literackich, Warszawa 1987 , s. 119. 
wspomniana książka Czy Bóg potrzebuje Kościoła?, a obok niej dwie inne: Ostatni dzień Jezusa. Co stało się w Wielki Piątek? ${ }^{69}$ oraz najnowsze dzieło Gerharda Lohfinka pt. Czy Jezus głosił utopię?70. Książka ta powstała na podstawie cyklu wykładów, które G. Lohfink wygłosił w Poznaniu i Krakowie w maju 2006 r. na zaproszenie redakcji dominikańskiego wydawnictwa „W drodze” oraz Wydziału Teologicznego Uniwersytetu im. Adama Mickiewicza w Poznaniu. Polski czytelnik mógł wziąć ją do ręki jako pierwszy. Wszystkie te dzieła ukazały się staraniem wydawnictwa "W drodze”. Niewątpliwie publikacje te przyczynią się do przybliżenia myśli Gerharda Lohfinka pośród szerszej rzeszy czytelników. Dotychczas bowiem, jego dzieła były znane tylko wąskiej grupie specjalistów, biblistów i teologów. Czy Jezus głosił utopię? doskonale wpisuje się w ciąg myśli teologicznej Lohfinka. Jest to dzieło głęboko zakorzenione w Katolickiej Gminie Zintegrowanej, o której pisze, że bez teologii i życia w niej nie byłby w stanie napisać tej książki, a zwłaszcza omówionego tu rozdziału o modlitwie Pańskiej, dla którego wskazówki zaczerpnął również z rozmów z bratem Norbertem ${ }^{71}$.

Książka ta, mimo że nie należy do wielkiego kwartetu dzieł Lohfinka i tylko częściowo jest wynikiem nowego projektu badawczego, to jednak zasługuje na naszą szczególną uwagę. Zwłaszcza ze względu na najobszerniejszy rozdział (ss. 61-136) poświęcony modlitwie Ojcze nasz. Modlitwę tę Lohfink prowokacyjnie określa „niebezpieczną modlitwą”, ale czy rzeczywiście chodzi tylko o prowokację? Refleksja teologiczno-egzegetyczna nad Ojcze nasz, jest nowym spojrzeniem $^{72}$ na najczęściej odmawianą modlitwę chrześcijan. Jest to publikacja tym cenniejsza, że na rynku polskim nie dysponujemy zbyt wieloma opracowaniami odnośnie do tego zagadnienia ${ }^{73}$. Autor modlitwę Ojcze nasz rozważa na tle tekstów Starego i Nowego Testamentu, przywołując Sitz im Leben każdej z próśb i posługując się kluczem hermeneutycznym w postaci idei królestwa Bożego. W tym świetle modlitwa ta nie tylko, że odzyskuje dawny blask, przysłonięty

${ }^{69}$ Tytuł org. G. Lohfink, Der letzte Tag Jesu. Was bei der Passion wirklich geschah, Freiburg im Breisgau 1981.

${ }^{70}$ Tyt. org. Das Reich Gottes eine Utopie? Po raz pierwszy książka ukazała się w języku polskim, Poznań 2006. Zob. wstęp do książki oraz prywatna korespondencja: O. Cyprian Klahs. Redaktor naczelny „W drodze” - M. Rychert, 5.12.2006 r.

${ }^{71}$ G. Lohfink, Czy Jezus głosit utopię?, Poznań 2006, s. 182.

${ }^{72}$ Jedna z próśb „Święć się imię Twoje” została dość gruntownie omówiona w Wie hat Jesus Gemeinde gewollt? Omówienie pozostałych próśb stanowi materiał omawianej książeczki.

${ }^{73}$ J. Drozd, Ojcze nasz - Modlitwa Pańska, Katowice 1983; A. Borowski, J. L. Kontkowski, Z. Szymanek, Ojcze nasz, Kraków 1999; oraz artykuły M. Czajkowski, Ojcze nasz na tle kultury modlitwy w ówczesnej Palestynie, s. 181-202, w: Bóg - Dekalog - Błogostawieństwa - Modlitwa, red. A. Święcicki, Kraków 1977; E. Beaucamp, O co prosimy dla siebie w modlitwie "Ojcze nasz", Communio 5 (1985) 4, s. 81-84; C. Point, "Ojcze nasz, któryś jest w niebie...", Communio 19 (1999) 2, s. 136-141. 
przyzwyczajeniem, ale również zostaje przywrócony jej radykalny ewangeliczny charakter. Książka ta jest przykładem łączenia pastoralnego powołania z pasją egzegetyczną ${ }^{74}$.

Recepcja myśli Lohfinka dokonywała się niezależnie od przekładów jego dzieł na język polski. Wielu polskich teologów i egzegetów odnosiło się do jego dorobku naukowego. Chcemy zwrócić uwagę szczególnie na te obszary teologii tybińczyka, które pojawiają się nie tylko jako materiał cytowany lub umieszczany w bibliografii polskich autorów, ale ponadto stały się przedmiotem dyskusji i sporów. Obecność Lohfinka w polskich opracowaniach teologicznych ujawnia się w następujących obszarach tematycznych: 1) geneza Kościoła, 2) Kazanie na Górze, 3) możliwość realizacji nakazów moralnych, 4) adresaci przepowiadania Jezusowego, ponadto pojawiają się liczne odniesienia do prac Lohfinka przy okazji egzegezy niektórych przypowieści.

Najczęściej polscy autorzy odwołują się również w sposób krytyczny do zagadnienia genezy Kościoła. H. Lagkammer uważa, że teza Lohfinka, według której pytania o wskazanie momentu powstania Kościoła, a więc czy Jezus chciał, czy organizował, czy założył Kościół, nie są w ogóle uzasadnione, jest tezą odosobnioną, w której nie zauważa się, że Kościół jest czymś nowym, jest Kościołem Chrystusowym. Nowość tę próbuje wyjaśnić, odwołując się do analogicznego zagadnienia stosunku do Prawa Starego Testamentu. Między nauczaniem Jezusa a Prawem jest kontynuacja jednakże niekoniecznie po prostej linii. Tak jak Jezus mówi o „nowym” winie i „nowych bukłakach”, dając do zrozumienia, że nie myśli o kontynuacji, co więcej widzi bezsens jakiejkolwiek próby reperacji, tak samo należy mówić o nowości Kościoła, Jezus tworzy coś nowego, ${ }^{75}$ a nie tylko gromadzi lud Izarela. H. Seweryniak, który przytacza dyskusję, jaką prowadzi H. Lagkammer z G. Lohfinkiem w swoim dziele poświęconym eklezjologii Nowego Testamentu, zwraca słusznie uwagę na nieco inny aspekt myśli Lohfinka, twierdząc, że powstanie Kościoła nie oznacza odrzucenia czy potępienia Izraela, to bowiem Izrael był adresatem przesłania zbawczego, którego Jezus chciał zgromadzić i uczynić zeń prawdziwy Lud Boży ${ }^{76}$. H. Seweryniak w kwestii założenia Kościoła przyjmuje stanowisko Międzynarodowej Komisji Teologicznej, która w dokumencie „Wybrane tematy z eklezjologii" (7.10.1985 r.) wymienia dziesięć faz w procesie formowania się Kościoła ${ }^{77}$, twierdząc, że żadnej z nich nie można uważać jako oddzielny

${ }^{74}$ Tak było również w przypadku wielu innych dzieł: Wie hat Jesus Gemeinde gewollt?, Jesus Anfrage an uns.

${ }^{75}$ H. Lagkammer, Nowy Testament o Kościele, s. 21-22.

${ }^{76}$ H. Seweryniak, Święty Kościót powszedni, s. 27-28.

77 Wybrane zagadnienia z eklezjologii, s. 197-236, w: Od wiary do teologii. Dokumenty Międzynarodowej Komisji Teologicznej 1969-1996, (red.) J. Królikowski, Kraków 2000. Por. 
moment fundacyjny ${ }^{78}$. Warto tu wskazać, ze stanowisko Komisji wyrażone w dokumencie końcowym oddaje zasadniczą myśl Lohfinka zawartą w Die Sammlung Israels. Choć zwraca się uwagę, że spośród wszystkich wydarzeń eklezjotwórczych dwa z nich „wyrażają w szczególny sposób przekonanie, że Kościół jest założony przez Jezusa z Nazaretu: pierwsze to nadanie św. Piotrowi imienia $\mathrm{w}$ następstwie jego wyznania wiary mesjańskiej (por. Mk 3,16) i obietnica założenia Kościoła (por. Mt 16,16n.); drugie to ustanowienie Eucharystii (por. Mk 14,22n.; Mt 26,26n.; Łk 22,14; 1 Kor 11,23) - wskazując, że - logia Jezusa odnoszące się do Piotra i opis Ostatniej Wieczerzy mają rzeczywiście pierwszorzędne znaczenie w dzisiejszej dyskusji na temat pochodzenia Kościo$ł a^{\prime \prime 79}$. Z dokumentu Międzynarodowej Komisji Teologicznej wynika, że żaden z etapów nie może być traktowany oddzielnie jako moment założycielski. „Całe bowiem dzieło i życie Jezusa jest w pewien sposób korzeniem i fundamentem Kościoła. [...] Powstanie Kościoła zakłada całość zbawczego dzieła Jezusa w Jego śmierci, zmartwychwstaniu i zesłaniu Ducha Świętego" ${ }^{\prime 0}$. Kościół nie jest wynikiem jednorazowego aktu założycielskiego zdeterminowanego historycznie, ale raczej efektem procesu „rodzenia się”81. Założenie Kościoła jest procesem historio-zbawczym. Z pełną akceptacją dla stanowiska tybinczyka odnoszą się J. Kudasiewicz ${ }^{82}$ oraz W. Rakocy ${ }^{83}$.

Druga kwestia, jaką podnosi H. Lagkammer, dotyczy adresatów orędzia Jezusa. Zgadza się, że „Jezus głównie i w pierwszym rzędzie został posłany do „Synów Izraela”. Nie znaczy to jednak, że swoją misję zbawczą ekskluzywnie

S. Pié-Ninot, Gesù e la chiesa, s. 159-160, w: red. R. Latourelle, R. Fisichella, Dizionario di teologia fondamentale, Assisi 1990, s. 151-162.

${ }^{78}$ H. Seweryniak, Święty Kościót powszedni, s. 27.

${ }^{79}$ Wybrane zagadnienia z eklezjologii, s. 201.

${ }^{80}$ Tamże.

${ }^{81}$ Zwrot "rodzenie się“" wskazuje na pewien proces, stąd lepiej wyraża sposób wyłaniania się i zaistnienia Kościoła niż takie pojęcia, jak: „powstanie” i „założenie”. G. Lohfink chętnie odwołuje się do tego zwrotu. Por. La raccolta d'Israele, s. 15, 36, 116, 117. Z polskich teologów H. Seweryniak docenia wymowę tego zwrotu w opisie eklezjogenezy. Por. Święty Kościót powszedni, s. 27. H. Seweryniak wskazuje na następujące momenty eklezjotwórcze: Jezusowe głoszenie Królestwa Bożego, wybór Dwunastu, powołanie i funkcja Piotra, Ostatnia Wieczerza, krzyż i zmartwychwstanie oraz zesłanie Ducha Świętego. Por. tenże, Świadectwo $i$ sens, s. 405-413. H. Fries w swoim wielkim dziele, komentując nauczanie Soboru Watykańskiego II o praeparatio ecclesiae, wskazuje, że „w Izraelu i w Starym Przymierzu przygotowuje się Kościół Jezusa Chrystusa" (s. 453). Zagadnienie praeparatio ecclesiae w Starym Testamencie omawia bardzo szeroko (s. 437-457), aby przejść do ukazania etapów formowania się Kościoła w Nowym Testamencie.

${ }^{82}$ J. Kudasiewicz, Ewangelie synoptyczne dzisiaj, s. 264.

${ }^{83}$ W. Rakocy, "Będziecie moimi świadkami...” (Dz 1,8) (Dzieje Apostolskie), s. 32 i 35, w: Wprowadzenie w myśl i wezwanie ksiąg biblijnych. Dzieje Apostolskie. Listy św. Pawła, red. J. Frankowski, S. Mędala, Warszawa 1997, s. 13-81. 
zacieśnił i zamknął, że oprócz Izraela nikt nie miał już szans zbawczych." Dla uwydatnienia swojego stanowiska rozróżnia między zasadniczą misją Jezusa a locum tej misji, jakie stanowił naród żydowski. Przyznaje jednakże, że również pierwsi misjonarze chrześcijańscy kontynuowali najpierw swoją misję pośród narodu izraelskiego ${ }^{84}$. Czy jednak zarzut ekskluzywizmu zbawczego jest trafny?

Lohfink już w Die Sammlung Israels formuje w tym względzie jasne stanowisko, któremu jest wierny w następnych dziełach. Izrael zostanie odnowiony i jako taki obejmie sobą także ludy pogańskie. Po zmartwychwstaniu apostołowie zostają posłani do tego Izraela, który rozszerzy się poza Jerozolimę, Judeę, Samarię, aż po krańce ziemi ${ }^{85}$. W ten sposób poprzez pośrednictwo prawdziwego Izraela również poganie zostają włączeni w eschatologiczny lud Boży, co było szczególnym znakiem mesjańskim wypełnienia się proroctw starotestamentalnych. Ludy pogańskie uzyskają zbawienie na tyle, na ile stają się częścią Izraela $^{86}$. Eschatologiczny Izrael zatem nie stanowi społeczności o charakterze narodowym i ekskluzywistycznym, ale historyczno - zbawczym ${ }^{87}$. Doskonale intencję tybińczyka podchwycił J. Flis, stwierdzając: „Prawdziwy Izrael jest tam, gdzie jest Kościół, tzn. Piotr, Apostołowie i Duch ożywiający wszystkich wierzących" ${ }^{\prime 88}$. Tym samym należy stwierdzić, że zarzut ekskluzywizmu mija się z przesłaniem Lohfinka odnośnie do teologii Izraela.

Kolejnym tematem, do którego odwołują się polscy teolodzy, jest symbolika Dwunastu. Lohfink przypisuje temu najbliższemu otoczeniu Jezusa funkcję symboliczną, zarodka eschatologicznego zgromadzenia dwunastu pokoleń Izraela ${ }^{89}$. Ideę tę za Lohfinkiem podejmują J. Flis ${ }^{90}$ czy H. Seweryniak ${ }^{91}$. Jest to teza charakterystyczna dla teologii Lohfinka, choć powszechnie przyjęta i obowiązująca we współczesnej teologii. Rysem oryginalnym jest włączenie symboliki Dwunastu w dynamiczny proces gromadzenia Izraela. Symbolika liczby Dwunastu wyraża się w działaniu.

Wreszcie tematem podzielanym z Lohfinkiem i obecnym $\mathrm{w}$ polskich opracowaniach jest temat adresatów i wykonalności etosu moralnego zawar-

${ }^{84}$ H. Lagkammer, Nowy Testament o Kościele, s. 24-25.

${ }^{85}$ G. Lohfink, La raccolta d'Israele, s. 97.

${ }^{86}$ Tenże, Gesù come voleva la sua comunità?, s. 35.

${ }^{87}$ Tenże, La raccolta d'Israele, s. 33-34.

${ }^{88}$ J. Flis, Modele Kościota w pismach narracyjnych Nowego Testamentu, s. 212. Odwołuje się do jeszcze innego źródła: G. Lohfink, Gottes Taten gehen weiter, Freiburg im Breisgau 1985, s. 30-32.

${ }^{89}$ G. Lohfink, Gesù come voleva la sua comunitŕ?, s. 23; zob. także, Jesus und die Kirche, red. W. Kern-Hermann, J. Pottmayer, M. Seckler, Handbuch der Fundamentaltheologie 3. Traktat Kirche, s. 76.

${ }^{90} \mathrm{~J}$. Flis, Modele Kościoła w pismach narracyjnych Nowego Testamentu, s. 224, zob. Die Sammlung Israels, s. 93-99.

${ }^{91}$ H. Seweryniak, Świadectwo $i$ sens, s. 408. 
tego w Kazaniu na Górze. J. Łach dokonuje znaczącego wyznania: „Osobiście byłem pod wrażeniem tego, co na ten temat napisał [...] G. Lohfink. Kierując się jego rozumowaniem, przyjmuję racje przemawiające za tezą, że Kazanie na Górze adresowane jest do nowego Izraela, a nie tylko do wybranych uczniów, do których należą przede wszystkim apostołowie i wszystkich obowiązują zawarte w kazaniu polecenia" ${ }^{\prime 92}$. Nie będzie chyba przesadnym stwierdzenie, że wyznanie to $\mathrm{z}$ ust ks. prof. Jana Łacha jest wyrazem szczególnego uznania. W tym też duchu temat ten podejmują w swoich działach i opracowaniach, J. Kudasiewicz ${ }^{93}$, w dziele poświęconym ewangeliom synoptycznym, a także M. Machinek w intrygującym artykule na temat Kazania na Górze ${ }^{94}$.

Jak mogliśmy już zauważyć, nie wszystkie z wymienionych, naszym zdaniem, sztandarowych dzieł tybińczyka zostało w Polsce zauważonych. W obszarze polskiej literatury teologicznej oprócz recenzji ${ }^{95}$ pojawił się jak dotąd tylko jeden artykuł i jedna rozprawa naukowa ${ }^{96}$ poświęcona teologii Lohfinka.

Na szeroki zasięg twórczości Lohfinka w Polsce wskazują z pewnością liczne odwołania, cytaty oraz obecność jego dzieł w bibliografii różnych opracowań egzegetycznych i teologicznych ${ }^{97}$. Warto tu wspomnieć chociażby wznowie-

92 J. Łach, "Konstytucja” królestwa Bożego (Mt 5-7; Łk 6, 20-49), s. 102, w: Ksiądz Rektor Jan Each Kaptan i Biblista, red. R. Bartnicki, Warszawa 2004, s. 65-435, zob. G. Lohfink, Wem gilt die Bergpredigt? Beiträge zu einer christlichen Ethik, s. 48-63.

${ }^{93}$ J. Kudasiewicz, Ewangelie synoptyczne dzisiaj, s. 230, zob. tamże, s. 18-38; M. Machinek, Kazanie na górze. Profetyczna prowokacja czy program życiowy?, s. 88-89, Ruch Biblijny i Liturgiczny 2 (1998), s. 87-101.

${ }^{94}$ M. Machinek, Kazanie na górze. Profetyczna prowokacja czy program życiowy?, Ruch Biblijny i Liturgiczny 2 (1998), s. 87-101.

${ }^{95}$ S. Moysa, [Rec.] Gerhard Lohfink, der letze Tag Jezu. Die Ereignisse der Passion, Freiburg im Breisgau, Basel, Wien, 1981, Verlag Herder, CT 2 (1982), s. 218-219. A. Nowicki, [Rec.] Gerhard Lohfink, L'Eglise que voulait Jésus. Les editions du Cerf. Paris 1985, Colloquium Salutis, 18-19, 1986-1987, s. 375-380. S. Grzybek, [Rec.] Gerhard Lohfink, Rozumieć Biblie, Warszawa 1987, ttum. polskie B. Widta, ss. 142, RBL 6 (1987), s. 542-544. E. Strycharz, [Rec.] Gerhard Lohfink, Rozumieć Biblię. Wprowadzenie do krytyki form literackich. PAX, Warszawa 1987, ss. 138, Katecheta 3 (1988) 185, s. 139-140. J. Łach, [Rec.] Gerhard Lohfink - Rudolf Pesch, Tiefenpsychologie und keine Exegese. Eine Auseinandersetzung mit Eugen Drewermann, Stuttgarter Bibelstudien 129, Stuttgart 1987, ss. 112, RBL 3 (1988), s. 270-271.

${ }^{96}$ M. Rychert, Spoteczno-historyczny wymiar królestwa Bożego w teologii Gerharda Lohfinka, Seminare 24 (2007), s. 177-190; tenże, Teologia królestwa Bożego według Gerarda Lohfinka. Praca doktorska. Wydział Teologiczny UMK w Toruniu $2007 \mathrm{r}$.

${ }^{97}$ Wykaz książek i artykułów zawierający publikacje autorów polskich odwołujących się do dzieł G. Lohfinka podane w porządku alfabetycznym: J. Flis, Modele Kościoła w pismach narracyjnych Nowego Testamentu, Lublin 1999 (cyt. s. 212). B. Górka, Kościót jako Królestwo Syna Człowieczego, Kraków 1997 (cyt. s. 147). K. Góźdź, Teologia historii zbawienia wedtug Oscara Cullmanna, Lublin 1996, (cyt. s. 272). M. Jagodziński, Comminio dzięki komunikacji. Teologiczny wymiar teorii komunikatywnego dziatania w eklezjologii Medarda Kehla SJ, Radom 2002 (cyt. s. 122). A. Kubiś, Rozwój eklezjologii katolickiej. Teologia fundamentalna, t. IV: 
nie, uzupełnionego między innymi w bibliografię dwóch z najważniejszych dzieł Lohfinka, książki Ewangelie synoptyczne dzisiaj, ks. J. Kudasiewicza. Należy jednak zwrócić uwagę, że spektrum dorobku naukowego tybińczyka, do którego odnoszą się polscy teolodzy, jest raczej zawężone do kilku dzieł i artykułów ${ }^{98}$. Tylko nieliczni powołują się i umieszczają w bibliografii więcej niż jedną jego pracę.

Niewątpliwie ostatnio wydane trzy dzieła Lohfinka, pobyt w Polsce i kontakt osobisty ze słuchaczami wykładów przyczynią się do pełniejszej recepcji jego teologii. Jest to egzegeta, którego działa są godne uwagi, pobudzają do refleksji, a niejednokrotnie wyrywają z utartych schematów myślowych. Z całą pewnością G. Lohfink należy do tych teologów, którzy ze względu na imponujący dorobek naukowy, świeżość spojrzenia oraz novum zawarte w myśli teologicznej domagają się pogłębionych studiów i rzetelnego opracowania.

\section{BIBLIOGRAFIA}

\section{KSIĄŻKI:}

Paulus vor Damaskus, Arbeitsweisen der neuen Bibelwissenschaft dargestellt an den Texten Apg 9,1-19; 22,3-21; 26,9-18, Stuttgart 1965.

Die Bibel: Gotteswort in Menschenwort, Stuttgart 1970.

Die Himmelfahrt Jesu. Untersuchungen zu den Himmelfahrts- und Erhöhungstexten bei Lukas, München 1971.

Kościót Chrystusowy, (red.) T. Dzidek, Ł. Kamykowski, A. Kubiś, A. Napiórkowski, Kraków 2003, s. 25-70. J. Kudasiewicz, Ewangelie synoptyczne dzisiaj, Ząbki 2006 (cyt. s. 230, 264). H. Lagkammer, Nowy Testament o Kościele, Wrocław 1995 (cyt. s. 21, 22, 24). Tenże, Pytanie o przedpaschalne powstanie Kościoła, Roczniki Teologiczne 44 (1997) 1, s. 139-146. I. S. Ledwoń, „... i nie ma w żadnym innym zbawienia”, Lublin 2006. J. Łach, „Konstytucja" Królestwa Bożego (Mt 5-7; Łk 6,20-49), w: Ksiądz Rektor Jan Each Kaptan i Biblista, red. R. Bartnicki, Warszawa 2004, s. 65-435 (cyt. s. 88, 93, 102, 353, 354). M. Machinek, Kazanie na górze. Profetyczna prowokacja czy program życiowy?, Ruch Biblijny i Liturgiczny 2 (1998), s. 87-101 (cyt. s. 88, 100). J. Neumann, Idea zbawcza Królestwa Bożego, Warszawa 2000 (cyt. s. 39, 40). A. Nowicki, Kościót w horyzoncie królestwa Bożego, Wrocław 1995 (cyt. s. 139). A. Paciorek, Ewangelia wedtug Świętego Mateusza, t. 1/cz. 1, Częstochowa 2005. K. Romaniuk, Powołanie w Biblii, Warszawa 1989. H. Seweryniak, Święty Kościót powszedni, Warszawa 1996 (cyt. s. 27, 28, 32). Tenże, Świadectwo $i$ sens, Płock 2005 (cyt. s. 408). M. Skierkowski, „A swoi Go nie przyjęli" (J 1, 11), Warszawa 2006. S. Włodarczyk, Nowy lud Boży w myśli teologicznej św. Eukasza, Częstochowa 2008 (cyt. s. 5). Wprowadzenie w myśl $i$ wezwanie ksiąg biblijnych. Dzieje Apostolskie. Listy św. Pawła, red. J. Frankowski, S. Mędala, Warszawa 1997 (cyt. s. 32, 34, 35, 63, 79).

${ }^{98}$ Do najczęściej cytowanych dzieł G. Lohfinka należą: Die Sammlung Israels. Eine Untersuchung zur lukanischen Ekklesiologie, München 1975; Wem gilt die Bergpredigt? Beiträge zu einer christlichen Ethik, Freiburg im Breisgau 1988; Wie hat Jesus Gemeinde gewollt? Zur gesellschaftlichen Dimension des christlichen Glaubens, Freiburg 1982; Das Gleichnis vom Sämann (Mk 4,3-9), Biblische Zeitschrift 30 (1986) 1, s. 36-69; Gottes Taten gehen weiter, Freiburg im Breisgau 1985. 
Die Himmelfahrt Jesu. Erfindung oder Erfahrung?, Sttutgart 1972.

Gott ohne Masken. Predigten und Ansprachen, Würzburg 1972.

Jetzt verstehe ich die Bibel. Ein Sachbuch zur Formkritik, Stuttgart 1973 (tłum. pol. Rozumieć Biblię: Wprowadzenie do krytyki form literackich, Warszawa 1987).

Die Sammlung Israels. Eine Untersuchung zur lukanischen Ekklesiologie, München 1975.

Der Tod ist nicht das letzte Wort. Meditationen, Freiburg im Breisgau 1976.

Glaube braucht Erfahrung. Predigten und Ansprachen, Würzburg 1977.

Der letzte Tag Jesu. Was bei der Passion wirklich geschah, Freiburg im Breisgau 1981 (tłum. pol. Ostatni dzień Jezusa. Co stało się w Wielki Piątek, Poznań 2006).

Wie hat Jesus Gemeinde gewollt? Zur gesellschaftlichen Dimension des christlichen Glaubens, Freiburg im Breisgau 1982.

Gottes Taten gehen weiter. Geschichtstheologie als Grundvollzug neutestamentlicher Gemeinden, Freiburg im Breisgau 1985.

Wem gilt die Bergpredigt? Beiträge zu einer christlichen Ethik, Freiburg im Breisgau 1988.

Der niemals gekündogte Bund. Exegetische Gedanken zum christlich-jüdischen Gespräch, Freiburg im Breisgau 1989.

Studien zum Neuen Testament, Stuttgart 1989.

Braucht Gott die Kirche? Zur Theologie des Volkes Gottes, Freiburg im Breisgau 1998 (tłum. pol. Czy Bóg potrzebuje Kościoła?, Poznań 2006).

Gottes Volksbegehren. Bbiblische Herausforderungen, München 1998.

Mitherausgeber der drei Bände: Die Feier des Sonntags. Auslegungen der Schrifttexte. Lesejahr A / Lesejahr B / Lesejahr C, Bad Tölz 2001.

Auf der Erde, wo sonst? Ein theologisches Tagebuch, Bad Tölz 2003.

Bibel ja - Kirche nein?, Bad Tölz 2004.

Czy Jezus głosit utopię?, Poznań 2006.

\section{ARTYKUŁY I PRACE ZBIOROWE:}

Der historische Ansatz der Himmelfahrt Christi, Catholica 17 (1963), s. 44-84.

Eine alttestamentliche Darstellungsform für Gotteserscheinungen in den Damaskusberichten (Apg 9; 22. 26), Biblische Zeitschrift 9 (1965) 2, s. 246-257. s. $108-115$.

"Meinen Namen zu tragen..." (Apg 9,15), Biblische Zeitschrift 10 (1966) 2,

Christologie und Geschichtsbild in Apg 3, 19-21, Biblische Zeitschrift 13 (1969) 2, s. 223-241.

G. Lohfink, R. Schnackenburg, J. Lange, E. Zenger, Jesus Anfrage an uns, Würzburg 1972.

Gab es im Gottesdienst der neutestamentlichen Gemeinden eine Anbetung Christi?, Biblische Zeitschrift 18 (1974) 2, s. 161-179.

Jesus und die Ehescheidung. Zur Gattung und Sprachintention von Mt 5,32, w: Biblische Randbemerkungen, (red.) R. Schnackenburg, Würzburg 1974, s. 207-217.

Bemerkungen zur neuen Einheitsübersetzung der Bibel. Übersetzungsfehler in der Apostelgeschichte, Theologische Quartalschrift 155 (1975) 3, s. 244-246.

Der Losvorgang in Apg 1,26, Biblische Zeitschrift 19 (1975) 2, s. 247-249. 
"Ich habe gesündigt gegen den Himmel und gegen dich" Eine Exegese von Lk 15, 18.21, Theologische Quartalschrift 155 (1975) 1, s. 51-52.

Zur Möglichkeit christlicher Naherwartung, w: G. Greshake, G. Lohfink, Naherwartung - Auferstehung - Unsterblichkeit: Untersuchungen zur christlichen Eschatologie, Freiburg im Breisgau 1975, s. 38-81.

Das Zeitproblem und die Vollendung der Welt, w: G. Greshake, G. Lohfink, Naherwartung - Auferstehung - Unsterblichkeit: Untersuchungen zur christlichen Eschatologie, Freiburg im Breisgau 1975, s. 131-155.

Was kommt nach dem Tod?, w: G. Greshake, G. Lohfink, Naherwartung - Auferstehung - Unsterblichkeit: Untersuchungen zur christlichen Eschatologie, Freiburg im Breisgau 1975, s. 133-149. s. $35-54$.

Der Ursprung der christlichen Taufe, Theologische Quartalschrift 156 (1976) 1,

Das Bittgebet und die Bibel, Theologische Quartalschrift 157 (1977) 1, s. 23-26.

Die Normativität der Amtsvorstellungen in den Pastoralbriefen, Theologische Quartalschrift 157 (1977) 2, s. 93-106.

Universalismus und Exklusivität des Heils im Neuen Testament, w: (red.) K. Kertelge, Absolutheit des Christentums, Freiburg im Breisgau 1977, s. 63-82.

Die Grundstruktur des biblischen Bittgebets, s. 19-31, w: Bittgebet - Testfall des Glaubens, (red.) G. Lohfink, G. Greshake, Mainz 1978, s. 19-31.

Gibt es noch Taten Gottes?, Orien 42 (1978), s. 124-126.

Die Seite der Herausgeber. Gehört die Jungfrauengeburt zur biblischen Heilsbotschaft?, Theologische Quartalschrift 159 (1979) 4, s. 304-306.

Der Ablauf der Osterereignisse und die Anfänge der Urgemeinde, Theologische Quartalschrift 160 (1980) 3, s. 162-176.

Die Unbedingtheit und die Faszination im Leben Jesu, Erbe und Auftrag 56 (1980), s. $89-98$.

Hat Jesus eine Kirche gestiftet?, Theologische Quartalschrift 161 (1981) 2, s. $81-97$.

Paulinische Theologie in der Rezeption der Pastoralbriefe, w: (red.) K. Kertelge, Paulus in den neutestamentlichen Spätschriften. Zur Paulusrezeption im Neuen Testament, Freiburg im Breisgau 1981, s. 70-121.

Der ekklesiale Sitz im Leben der Aufforderung Jesu zum Gewaltverzicht (Mt 5, 39b-42/ Lk 6, 29f), Theologische Quartalschrift 162 (1982) 3, s. 236-253.

Weibliche Diakone im Neuen Testament, w: (red.) G. Dautzenberg, Die Frau im Urchristentum, Freiburg im Breisgau 1983, s. 320-338.

Wem gilt die Bergpredigt? Eine redaktionskritische Untersuchung von Mt 4, 23 - 5,2 und 7,28f, Theologische Quartalschrift 163 (1983) 4, s. 264-284.

Das Weinwunder zu Kana. Eine Auslegung von Joh 2,1-12, Geist und Leben 57 (1984) 3, s. 169-182.

Gesetzeserfüllung und Nachfolge. Zur Radikalität des Ethischen im Matthäusevangelium, w: (red.) H. Weber, Der ethische Kompromiß. Studien zur theologischen Ethik 12, Freiburg im Breisgau 1984, s. 15-58.

G. Lohfink, N. Lohfink, "Kontrastgesellschaft". Eine Antwort an David Seeber, Herder Korrespondenz 38 (1984) 4, s. 189-192.

Wie Gott tröstet, Christ in der Gegenwart 36 (1984) 133. 
Jesus und die Kirche, w: (red.) W. Kern-Hermann, J. Pottmayer, M. Seckler, Handbuch der Fundamentaltheologie 3. Traktat Kirche, Freiburg im Breisgau 1985-1998, s. 49-96.

Die Metaphorik der Aussaat im Gleichnis vom Sämann (Mk 4, 3-9), w: À cause de l'Èvangile. Ètudes sur les Synoptiques et les Actes. Mélanges offerts au Dom Jacques Dupont, O.S.B.à l'occasion de son 70e anniversaire, Paris 1985, s. 211-228.

Wenn wir ihn so weitermachen lassen... (Gv 11,45-53), Orien 48 (1984), s. 62n.

Die Korrelation von Reich Gottes und Volk Gottes bei Jesus, Theologische Quartalschrift 165 (1985) 3, s. 173-183.

Das Gleichnis vom Sämann (Mk 4,3-9), Biblische Zeitschrift 30 (1986) 1, s. $36-69$.

Senfkorn und Weltenbaum (Mk 4, 30-32 Parr). Zum Verhältnis von Natur und Gesellachaft bei Jesus, w: (red.) H. Schweizer, „...Bäume braucht man doch!“. Das Symbol des Baumes zwischen Hoffnung und Zerstörung, Sigmaringen 1986, s. 109-126.

Schwerter zu Pflugscharen! Die Rezeption von Jes 2,1-5 par Mi 4,1-5 in der Alten Kirche und im Neuen Testament, Theologische Quartalschrift 166 (1986) 3, s. $184-209$.

Jesu Verbot der Ehescheidung und seine Adressaten, Theologische Quartalschrift 167 (1987) 2, s. 144-146.

G. Lohfink, R. Pesch, Tiefenpsychologie und keine Exegese: Eine Auseinandersetzung mit Eugen Drewermann, Stuttgart 1987.

Die Not der Exegese mit der Reich-Gottes-Verkündigung Jesu, Theologische Quartalschrift 168 (1988) 1, s. 1-15.

Die Vermittlung des Paulinismus zu den Pastoralbriefen, Biblische Zeitschrift 32 (1988) 2, s. 169-188.

Das präexistente Heilsplan. Sinn und Hintergrund der dritten Vaterunserbitte, w: (red.) H. Merklein, Neues Testament und Ethik, Zum 75 Geburtstag R. Schnackenburg, Freiburg im Breisgau 1989, s. 110-135.

Wie werden im Reich Gottes die Hungernden satt? Zur Erzählintention von Mk 6,30-44, w: (red.) J. J. Degenhardt, Die Freude an Gott - unsere Kraft. Festschrift für Otto Bernhard Knoch zum 65 Geburtstag, Stuttgart 1991, s. 135-144.

Das Neue am Neuen Testament, w: "Wenn das Salz sine Kraft verliert". Ein Kirchenjachr mit der Integrierten Gemeinde in Paderborn, Urfeld 1992, s. 11-39.

Die Bibel als Buch der Kirche, Religionsunterricht an höheren Schulen 36 (1993), s. 388-405.

Zur Figur der Zwölf im Neuen Testament, w: Mit Jesus sein - von ihm gesandt. Dokumentation zum Priestertag am 3. Mai 1993 anläßlich des silbernen Bischofsjubilämus von Erzbischof Johannes Joachim Degenhardt, Paderborn 1993, s. 20-34.

Volk Gottes als "Neue Familie", w: (red.) J. Ernst, S. Leimgruber, Surrexit Dominus vere. Die Gegenwart des Auferstandenen in seiner Kirche, Paderborn 1995, s. 227-242.

Antijudaismus bei Paulus?: die Kirche und Israel in 1 Thess 2,14-16 und Röm 9-11, w: Radici dell'antigiudaismo in ambiente cristiano, Vaticano 2000, s. 163-196.

Die Feier des Sonntags. Lesejahr A. Auslegung der Schrifttexte, (red.) G. Lohfink, B. Lesejahr, R. Pesch, L. Weimer, Bad Tölz 2001.

Die Feier des Sonntags. Lesejahr B. Auslegung der Schrifttexte, (red.) G. Lohfink, B. Lesejahr, R. Pesch, L. Weimer, Bad Tölz 2002. 
Die Feier des Sonntags. Lesejahr C. Auslegung der Schrifttexte, (red.) G. Lohfink, B. Lesejahr, R. Pesch, L. Weimer, Bad Tölz 2003.

Am ersten Tag der Woche. Auslegungen der Schrifttexte. Lesejahr B, (red.) B. Koch, L. Weimer, G. Lohfink, Bad Tölz 2005.

Pytanie o prawidtowg formę ludu Bożego, W drodze 5 (381) 2005, s. 54-70.

\section{RECENZJE:}

Urlich Luz, Das Ewangelium nach Matthäus. 1. Teilband: Mt 1-7 (EKK I/1). Einsiedeln: Benziger; Neukirchen-Vluyn: Neunkirchener Verlag 1985. 420 S. Kart., w: Theologische Quartalschrift 3 (1985), s. 244-245.

Helmut Merklein, Jesu Botschaft vin der Gottesherrschaft. Eine Skizze (Stuttgarter Bibelstudien 111). Stuttgart: Kath. Bibelwerk 1983. 189 S. Kart., w: Theologische Quartalschrift, 2 (1984), s. 149-151.

Rudolf Pesch, Das markusevangelium 1. Teil: Einleitung und Kommentar zu Kapitel 1,1-8, 26 (HThK 2). Freiburg-Basel-Wien 1976, XXIV + 424 Seiten, gebunden, w: Theologische Quartalschrift 4 (1977), s. 301.

\section{GERHARD LOHFINK - LA SUA VITA, ATTIVITÀ SCIENTIFICA E LA RECENZIONE DELLA SUA TEOLOGIA IN POLONIA}

\section{SOMMARIO}

L'anno scorso nel nostro paese hanno stampato tre libri del ben conosciuto in Europa esegeta tedesco G. Lohfink. Questo avvenimento crea una occasione sufficente per presentare meglio la sua vita, attivitŕ scientifica, le sue opere e la recenzione della sua teologia in Polonia.

G. Lohfink naque nel 1934. Dal 1973 è stato il professore dell'esegesi neotestamentaria all'università di Tibinga. Nel 1986 rinunciò l'insegnamento alla università e si trasferi a Monaco per vivere e lavorare nella comunità della Katholische Integrierte Gemmeinde (Comunità Cattolica d'Integrazione).

Fra le sue opere più importanti si deve nominare prima di tutto "La raccolta d'Israele" in cui cerca di rispondere alla domanda: la chiesa è stata fondata dal Gesù storico? Secondo lui, la chiesa nasce solo quando la maggior parte di Israele si sottrae al mesaggio di Gesù. L'evangelista Luca presenta la nascità della chiesa come un processo storico guidato da Dio. Lohfink si sottoscrive a questo concetto e concepisce la nascità della chiesa come un compimento della raccolta di Israele annunziata dai profeti.

La sua seconda opera imporatne è intitolata: “Gesù, come voleva la sua comunita?" In quella, l'autore spiega un progetto della comunità della Chiesa. Secondo lui, la comunità cristiana deve rappresentare ciò che Israele era chiamato a diventare. Per quello Gesù esige che la sua comunità sia una societŕ alternativa, dove si vive diversamente dal mondo contemporaneo basato solamente sulla violenza.

La terza opera di Lohfink riguarda il discorso della montagna che da sempre pone un programma alternativo di rinuncia alla vilenza e di amore al nemico. Per dare la risposta alla domanda messa nel titolo: "Per chi vale il discorso della montagna?", l'autore va oltre la prospettiva sia puramente politica sia quella privatistica. Secondo 
lui, luogo privileggiato della seguela di Gesù è la comunità cristiana in cui si compiono le promesse messianiche di una società nuova.

Alla fine si deve nominare il libro più recente: "Dio ha bisogno la Chiesa?" In esso Lohfink presenta la Chiesa come un risultato della storia della convocazione del popolo di Dio da Abramo fino ad oggi. L'autore dimostra come Dio ha sempre operato nella Chiesa nuovi inizi e che anche adesso continua attraverso le persone da lui prescelte e nel tempo ben definito a intervenire in mezzo al suo popolo.

Le opere di G. Lohfink si concentrano sulla ecclesiologia che rappresenta per lui un campo preferito della sua teologia, tutta nella ottica biblica del Regno di Dio, ma anche quella della teologia fondamentale.

Nel ambiente della teologia polacca Lohfink è stato conosciuto da anni dagli esperti della teologia e della sacra scrittura. Tra di loro ci sono alcuni che entrano nel discorso teologico con Lohfink, lo citano e conoscono le sue opere. Comunque l'autore non è tanto conosciuto. Come ho accennato all'inizio, nell' ultimo anno sono state stampate tre libri del nostro autore che danno la possibilità di conoscere meglio la sua brillante esegesi e la sua teologia. 